\title{
Natural hazard fatalities in Switzerland from 1946 to 2015
}

\author{
Alexandre Badoux ${ }^{1}$, Norina Andres ${ }^{1}$, Frank Techel ${ }^{2}$, and Christoph Hegg ${ }^{1}$ \\ ${ }^{1}$ Swiss Federal Research Institute WSL, Zürcherstrasse 111, 8903 Birmensdorf, Switzerland \\ ${ }^{2}$ WSL Institute for Snow and Avalanche Research SLF, Flüelastrasse 11, 7260 Davos, Switzerland \\ Correspondence to: Alexandre Badoux (badoux@wsl.ch)
}

Received: 29 June 2016 - Published in Nat. Hazards Earth Syst. Sci. Discuss.: 13 July 2016

Revised: 10 November 2016 - Accepted: 24 November 2016 - Published: 19 December 2016

\begin{abstract}
A database of fatalities caused by natural hazard processes in Switzerland was compiled for the period between 1946 and 2015. Using information from the Swiss flood and landslide damage database and the Swiss destructive avalanche database, the data set was extended back in time and more hazard processes were added by conducting an in-depth search of newspaper reports. The new database now covers all natural hazards common in Switzerland, categorised into seven process types: flood, landslide, rockfall, lightning, windstorm, avalanche and other processes (e.g. ice avalanches, earthquakes). Included were all fatal accidents associated with natural hazard processes in which victims did not expose themselves to an important danger on purpose. The database contains information on 635 natural hazard events causing 1023 fatalities, which corresponds to a mean of 14.6 victims per year. The most common causes of death were snow avalanches $(37 \%)$, followed by lightning ( $16 \%)$, floods $(12 \%)$, windstorms (10\%), rockfall (8\%), landslides $(7 \%)$ and other processes $(9 \%)$. About $50 \%$ of all victims died in one of the 507 single-fatality events; the other half were killed in the 128 multi-fatality events.

The number of natural hazard fatalities that occurred annually during our 70-year study period ranged from 2 to 112 and exhibited a distinct decrease over time. While the number of victims in the first three decades (until 1975) ranged from 191 to 269 per decade, it ranged from 47 to 109 in the four following decades. This overall decrease was mainly driven by a considerable decline in the number of avalanche and lightning fatalities. About $75 \%$ of victims were males in all natural hazard events considered together, and this ratio was roughly maintained in all individual process categories except landslides (lower) and other processes (higher). The ratio of male to female victims was most likely to be balanced when deaths occurred at home (in or near a building), a
\end{abstract}

situation that mainly occurred in association with landslides and avalanches. The average age of victims of natural hazards was 35.9 years and, accordingly, the age groups with the largest number of victims were the 20-29 and 30-39 year-old groups, which in combination represented $34 \%$ of all fatalities. It appears that the overall natural hazard mortality rate in Switzerland over the past 70 years has been relatively low in comparison to rates in other countries or rates of other types of fatal accidents in Switzerland. However, a large variability in mortality rates was observed within the country with considerably higher rates in Alpine environments.

\section{Introduction}

Every year, worldwide natural hazard events not only generate tremendous financial damage costs but also cause a large number of human fatalities (MunichRe, 2016). According to the NatCatSERVICE database of MunichRe, the average annual global loss of life due to natural catastrophes was 68000 over the last 10 years and 54000 over the last 30 years (23000 in 2015; Ins. Inf. Inst., www.iii.org/ fact-statistic/catastrophes-global).

In scientific literature, information and data sets on loss of human lives due to specific natural hazard processes cover various time periods and exist at different aggregation levels: at the global scale (e.g. Jonkman, 2005; Petley, 2012; Auker et al., 2013; Dowling and Santi, 2014), the continental scale (e.g. Di Baldassarre et al., 2010; Sepúlveda and Petley, 2015) and most commonly the regional/national scale (e.g. Guzzetti, 2000; Ashley and Ashley, 2008; Höller, 2009; Vranes and Pielke, 2009; Singh and Singh, 2015; Techel et al., 2016). Moreover, there are studies that describe the circumstances during specific catastrophic natural hazard 
events and/or assess the patterns and reasons behind the associated massive loss of life (e.g. Chowdhury et al., 1993; Tsai et al., 2001; Doocy et al., 2007; Jonkman et al., 2009; Ando et al., 2013).

While some authors have analysed natural hazard mortality data that include many hazard types (e.g. Shah, 1983; Noji, 1991; Borden and Cutter, 2008), the bulk of studies have focussed on a distinct hazard process. Jonkman (2005) studied statistics about loss of human life caused by various freshwater flood types (river floods, flash floods and drainage problems) on a global scale and for the period from 1975 to June 2002 based on the EM-DAT International Disaster Database. This investigation showed that, while flash flood events have the highest average mortality rate (deaths divided by number of affected persons), Asian river floods are most devastating in terms of the number of persons killed or affected. In addition, very high death tolls have been reported for coastal flood events (e.g. Chowdhury et al., 1993; Gerritsen, 2005; Jonkman et al., 2009; Kure et al., 2016) and tsunamis (e.g. Doocy et al., 2007; Inoue et al., 2007; Ando et al., 2013). However, these events were not included in Jonkman (2005) due to the rather limited availability of information. On a national scale, flood fatalities have been assessed by many authors for countries all around the world, such as the USA (Ashley and Ashley, 2008), India (Singh and Kumar, 2013), Pakistan (Paulikas and Rahman, 2015) and Australia (Coates, 1999; FitzGerald et al., 2010).

Petley (2012) assembled a global data set of fatalities from non-seismically triggered landslides that took place from 2004 to 2010 based on the Durham Fatal Landslide Database (DFLD). The total number of landslides and fatalities during the 7-year period turned out to be an order of magnitude larger than numbers suggested by other sources, and the study indicated that most fatalities occur in Asia. In a study focusing on fatalities caused by debris flows (often included in landslides studies), Dowling and Santi (2014) considered 213 events that occurred between 1950 and 2011 and during which a total of 77779 people were killed. Results of this global analysis provided evidence that more debris-flow fatalities tend to occur in developing countries. This is reflected in the median number of fatalities per recorded deadly debris flow which is 23 in developing countries and only six fatalities per flow in advanced countries (11 when considering all data; Dowling and Santi, 2014). The value is very high when compared to data for the European Alps, where, for example, torrential processes cause an annual number of fatalities of approximately 1.5 in Austria (Fuchs and Zischg, 2014). On a national scale, landslide events with fatal consequences were compiled by Guzzetti (2000) for events that occurred in present-day Italy from 1279 to 1999 . Fast mass movements, such as rockfall events, rockslides, rock avalanches and debris flows were included in this study and were found to have caused the largest number of fatalities.

Loss of life due to snow avalanches has been analysed by numerous authors, most often at a national level, e.g. for Aus- tria (e.g. Höller, 2009), France (e.g. Jarry, 2011), Norway (e.g. Kristensen, 1998) or Switzerland (e.g. Schneebeli et al., 1998), but also at a regional level, e.g. for the European Alps (Techel et al., 2016).

Loss of life related to meteorological hazard events, such as lightning and all the different types of windstorms, has also been the subject of many national and regional studies. In the USA, medium- to long-term data sets of windrelated deaths have been investigated, for example for tornados (Ashley, 2007) and hurricanes (Rappaport, 2000; Czajkowski et al., 2011), as well as for (non-tornadic) convective (Black and Ashley, 2010) and non-convective (Ashley and Black, 2008) high-wind events. While convective and non-convective high-winds can cause serious problems in Switzerland (e.g. WSL and BUWAL, 2001), tornadoes are much more rare but have caused fatalities, e.g. in the 1920s and 1930s (Bader, 2001). Various publications have presented national lightning data sets, for example from the UK (Elsom, 2001), India (Singh and Singh, 2015), Australia (Coates et al., 1993), Colombia (Navarrete-Aldana et al., 2014), USA (Holle, 2016; López and Holle, 1996; Curran et al., 2000) and Swaziland (Dlamini, 2009). Additionally, Holle (2016) summarised and synthesised lightning fatality data from 23 recent national-scale investigations from both developed and developing countries.

Geophysical events such as tsunamis and volcanic activity might not be very relevant for Switzerland, but are of considerable importance when assessing consequences of natural hazards at a global level (e.g. Auker et al., 2013). Earthquakes, in contrast, have occurred in Switzerland with dramatic effects, but events causing fatalities or large amounts of damage are rare. The Basel earthquake of 18 October 1356 is arguably one of the three most devastating natural hazard incidents of the last 1000 years in Switzerland (the other two being the Biasca rockslide/water surge in 1513/1515 and the Goldau rock avalanche in 1806) and is regarded as the strongest historically documented earthquake event in central Europe (Giardini et al., 2004). While the 1356 event destroyed large parts of Basel, the overall number of victims remains uncertain and estimates range from 300 to 2000 fatalities (Fäh et al., 2009). The highest estimates, however, were evaluated to be highly improbable by Fäh et al. (2009). For countries more frequently struck by seismic activity, various fatality databases exist (e.g. Vranes and Pielke, 2009).

In Switzerland, fatalities caused by floods, debris flows and landslides have been systematically collected since 1972 . They are recorded in the Swiss flood and landslide damage database (Hilker et al., 2009) and were briefly analysed by Schmid et al. (2004). Deaths due to rockfall incidents have been included in the database since 2002. For disastrous events causing loss of life that occurred before 1972, only partial and scattered information is available (e.g. Röthlisberger, 1991). In parallel, information on loss of life caused by snow avalanches in Switzerland has been collected since the hydrological year 1936/1937 by the WSL Institute for 
Snow and Avalanche Research SLF. To our knowledge, no systematic data acquisition of fatalities and damage induced by convective and non-convective high winds and lightning has been carried out at national scale in Switzerland.

In the study presented here, we compiled the available data on natural hazard fatalities mentioned above, extended the period covered by the database and expanded it to include all process types relevant for the study area. We present this new, detailed 70-year (1946-2015) data set of loss of life in Switzerland caused by floods, debris flows, landslides and hillslope debris flows, rockfall events and rockslides, windstorms, lightning strikes, earthquakes and avalanches. Temporal and spatial patterns in the results are discussed and the numbers of fatalities as well as the characteristics of the underlying incidents for different process types are assessed. Finally, we compare our data to similar data from other countries and regions and attempt to explain the differences qualitatively.

According to the Federal Constitution of the Swiss Confederation, the cantons and municipalities are responsible for ensuring the protection of the population against natural hazards. The aim of this study is to support authorities to better understand the occurrence of fatal incidents, to identify potential improvements in hazard prevention and to further reduce the number of victims of natural hazards.

\section{Study area}

Switzerland is located in central Europe between latitudes 45 and $48^{\circ} \mathrm{N}$, and between longitudes 5 and $11^{\circ} \mathrm{E}$, with a total area of $41285 \mathrm{~km}^{2}$ and an altitudinal range of 193 to $4634 \mathrm{~m}$ a.s.l. The Swiss Confederation consists of 20 cantons and 6 half cantons, and its territory can be roughly divided into four regions based on its geomorphology (see Fig. 1): the Alps (a high-altitude mountain range running across the central-south of the country), the Swiss Plateau (a relatively flat area between Lake Geneva and Lake Constance), the Prealps (the transitional area between the Alps and the Swiss Plateau) and the Jura (a hilly mountain range in the northwest). The population grew from 4.5 to 8.3 million people between 1946 and 2015 and is clustered mostly on the Swiss Plateau (over $60 \%$ of the total population is located on less than a third of the total area of the country). The Swiss climate is temperate but can vary regionally. In large parts of the Alps the mean annual rainfall is around $2000 \mathrm{~mm}_{\text {year }}{ }^{-1}$ or more, and along the Swiss Plateau this value amounts to $1000-1500 \mathrm{~mm}$ year $^{-1}$. Most precipitation falls in the summer months.

\section{Data and methods}

The data for this study were extracted from the Swiss flood and landslide damage database (Sect. 3.1) and the Swiss destructive avalanche database (Sect. 3.2). The data set (ex- cept for avalanches) was then extended (i) in time to include an additional period of 26 years back to the year 1946 and (ii) in breadth to include additional relevant natural hazard processes, such as lightning, windstorms and earthquakes, by carrying out an extensive newspaper search (Sect. 3.3 and 3.4).

\subsection{Swiss flood and landslide damage database}

Since 1972, fatalities and estimates of financial damage costs caused by naturally triggered floods, debris flows, landslides and (since 2002) rockfall events have been collected by the Swiss Federal Research Institute WSL in the Swiss flood and landslide damage database (Hilker et al., 2009; Badoux et al., 2014). Fatality and damage information is primarily provided by approximately 3000 Swiss newspapers and magazines, which are scanned daily by a media-monitoring company. Additional information is often compiled from insurance companies and the websites of public authorities such as the police and fire brigades. An in-depth description of the structure of the Swiss flood and landslide damage database was presented by Hilker et al. (2009). For this study, the database provided information on a total of 129 deaths due to floods, debris flows, landslides, hillslope debris flows or rockfall from 1972 to 2015.

\subsection{The Swiss destructive avalanche database}

Data on avalanche casualties since winter 1936/37 are stored in the destructive avalanche database from the WSL Institute for Snow and Avalanche Research SLF (Techel et al., 2015). In the 79 years from 1936/37 to 2014/15, 1255 avalanches killed 1961 people in Switzerland. We retrieved data for our study period from this database and considered cases that occurred (i) in settlement areas, (ii) on high-Alpine building sites, (iii) on transportation corridors (including roads and railway lines, ski runs and winter hiking trails, if any of these were officially open or if they were closed but the casualty was work related) and (iv) on hiking trails in summer if the trail was open and snow free.

We explicitly excluded all cases that occurred outside of transportation corridors and settlements (except hiking trails in summer; see (iv) above). Thus, cases associated with ski or snowshoe touring, and skiing or snowboarding away from open ski trails were not included in our data set. Also, we did not incorporate avalanche fatalities related to vehicles illegally driving on officially closed roads. The destructive avalanche database is considered complete for fatality data and data quality is generally very high. Thus, no systematic search of avalanche-related events in a newspaper was necessary. 


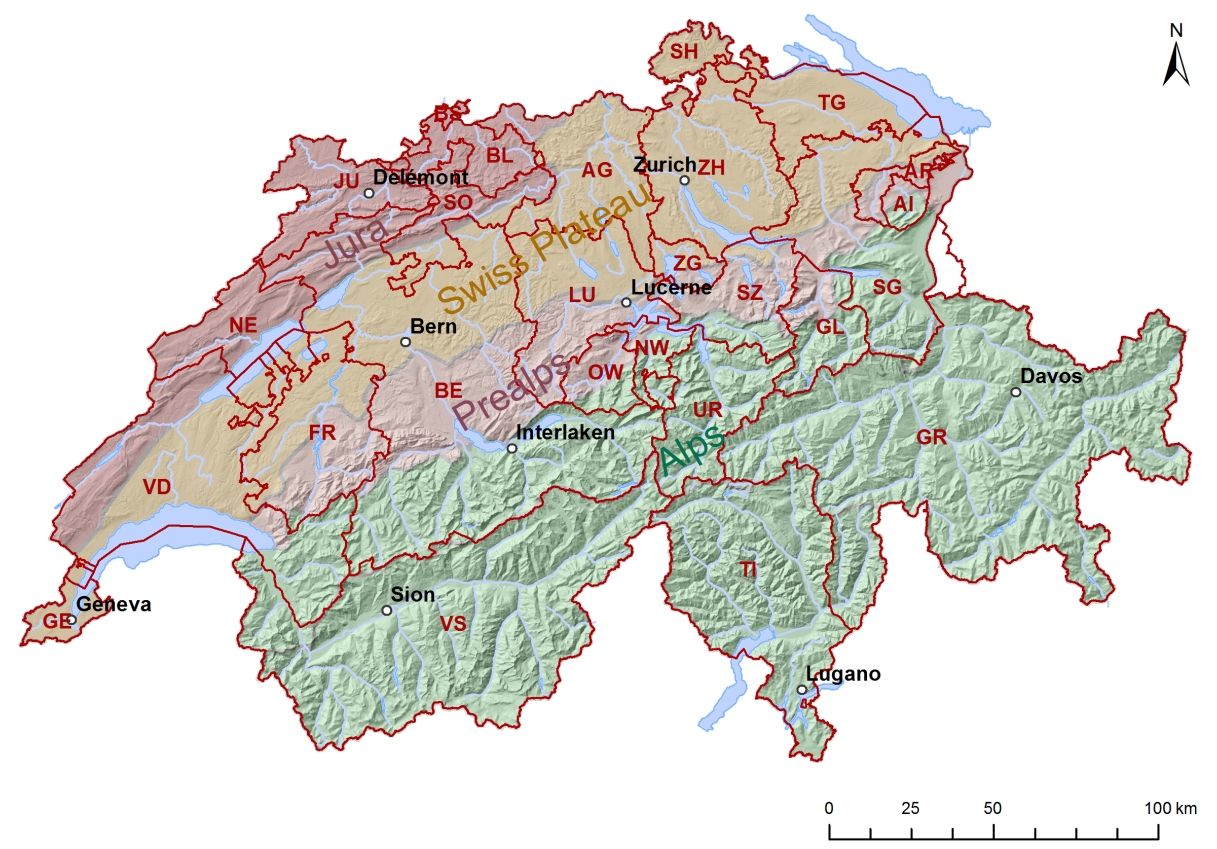

Figure 1. Study area showing the Swiss stream network, the Swiss cantons (red polygons with abbreviations; see BFS, 2016), the geomorphologic-climatic regions Jura, Swiss Plateau, Prealps, Alps (areas with different background colours) and several key cities (DHM source: $\mathrm{dhm} 25^{\circledR} 2016$ swisstopo, 5704000000$)$.

\subsection{Further extension of the record of natural hazard fatalities in Switzerland}

With the aim of extending the data series to 70 years and combining it with other natural hazard processes like windstorms, lightning, earthquakes and ice avalanches, we conducted a search in a newspaper. We selected the Neue Zürcher Zeitung (NZZ) because it is a national newspaper and a digital archive exists as far back as 1780. The NZZ is written in German, which is the most spoken language in Switzerland (see also Sect. 5.1). We accessed the digital archive via an internet platform, where a keyword search was possible. In a first step, we derived adequate keywords (in German) for the search. We selected the years 1986-1995, as a validation period, for which we already had some data from the Swiss flood and landslide damage database. We generated a list of possible keywords and checked how often these words were used in the newspaper for the description of casualties that occurred in Switzerland and abroad. The casualties from abroad were included to get more search hits. We then shortened the list to the most relevant keywords. Where possible, we combined the keywords for the different processes. For example, we searched for casualties caused by "flood OR inundation OR landslide OR landslip OR mudslide OR mudflow" combined with "dead OR casualty OR death OR human life OR drown OR killed OR dead body OR buried". An overview of the keywords and the combinations used is given in the supplementary material (Table S1 in the Supplement). With these keyword combinations, we found most cases (roughly $90 \%$ ) already stored in the Swiss flood and landslide damage database for the selected validation period 1986-1995.

In a next step, we used the selected keywords to scan the newspaper for the remaining years (1946-1985, 1996-2015). For the years for which we already had data from the Swiss flood and landslide damage database for the processes flood, landslide, debris flow and rockfall, we restricted the search to the processes not already covered. The search for fatalities produced up to 300 hits per year. We initially viewed all hits, but many were not relevant for our research (e.g. fatalities abroad). Further, the digital scan of the newspaper was sometimes of bad quality, which resulted in the misspelling of words and thus influenced our search because not all of our keywords were found. In addition, some gaps exist in the digital archive of the NZZ (e.g. 4-15 August 1978).

For each casualty found, a database entry was made. The following information describing the fatal accident and the victim was stored: name of municipality, canton, date, time, coordinates, description of the event, age, gender, locality (i.e. in or around a building, on a transportation route, in open terrain, in a stream channel, on a lake), mode of transport (on foot, by bicycle, in a private vehicle, by public transport, by boat, by ski), activity (work, leisure time) and data source. For most of the above-mentioned categories, the quality of the information was also assessed. In doing so, we distinguished between two types of information quality: (i) a concise statement describing a certain characteristic of the event (certain) and (ii) an indication of a characteristic that we de- 
duced based on the available information (probable). In contrast, if no information was available to describe certain aspects of a fatal incident, those characteristics were considered unknown.

\subsection{Natural hazard processes considered in the new database}

In the present study, we assigned the fatalities found in our search (or adopted from the flood and landslide damage database or the destructive avalanche database) to the following seven process categories.

- Flood includes people drowned in flooded or inundated areas or carried away in streams under high-water conditions.

- Landslide includes people killed by landslides, hillslope debris flows and channelised debris flows. Because debris flows were often not identified as such in the press media (especially in the first half of our study period), we decided to add debris-flow fatalities to the category of landslide processes. This approach has been applied previously, for example by Guzzetti (2000).

- Rockfall includes people killed by rockfall.

- Lightning includes people who died after being struck by lightning.

- Windstorm includes people killed by falling objects or trees during very strong wind conditions and people who drowned in lakes because their boat capsized during such conditions.

- Avalanche includes people killed in snow avalanches (except roof avalanches; see below).

- Other includes people killed by hazard processes that are not frequent in Switzerland (e.g. ice avalanches, earthquakes, lacustrine tsunamis, roof avalanches). Most of the fatalities assigned to this process type were caused by the 1965 Mattmark ice avalanche.

Fatalities due to forest fires did not occur during our study period and people who died during meteorological heat waves were not included. Overall, we considered only casualties in which people did not expose themselves to a considerable danger on purpose. For example, we excluded loss of life due to high-risk sports (e.g. canoeing and river surfing during floods) and other outdoor activities in potentially dangerous environments, such as canyoning, mountaineering and rock climbing. We also excluded popular snow sports experienced outside of ski resorts, such as out-of-bounds (offpiste) riding and Alpine touring, which have been described elsewhere (e.g. Techel and Zweifel, 2013; Schweizer and Lütschg, 2001). Further, we only included cases in which the process directly induced a casualty or an action that led to death. For example, we did not consider cases in which a forest ranger was killed during forest clearing operations after a windstorm or when a firefighter was killed in a flooded basement due to an electric shock.

\section{Results}

\subsection{Types of natural hazard processes associated with fatalities}

Our newly compiled database includes reports on 1023 fatalities associated with natural hazard processes in Switzerland during the period from 1946 to 2015 (Table 1). This result corresponds to an average of 14.6 fatalities per year. More than one-third of all fatalities (378 deaths) were caused by snow avalanches in winter and spring. The second most frequent cause of loss of life was lightning $(16.0 \%)$, followed by floods $(12.1 \%)$ and windstorms $(10.3 \%)$. Landslides and rockfall events each represented less than $10 \%$ of the total number of fatalities in Switzerland. Processes that caused sporadic deaths included an earthquake (3 deaths), a lacustrine tsunami (1) and a roof avalanche (1). The worst incident, in terms of the number of fatalities involved, that occurred during our 70-year study period was the catastrophic 30 August 1965 ice avalanche, which broke off at the terminus of the Allalin Glacier in the canton of Valais, destroyed the Mattmark Dam construction site and killed 88 people. This incident was the only deadly ice avalanche event we considered in the database (and is included in the category other processes; Table 1).

\subsection{Temporal distribution of natural hazard fatalities in Switzerland}

\subsubsection{Annual distribution of fatalities}

The annual number of natural hazard fatalities in Switzerland during our 70-year study period ranged from 2 (in 5 years and most recently in 2010) to 112 (in 1951; Fig. 2). The resulting median over the entire period was 9.0 deaths per year, which is below the mean value of 14.6 and highlights the influence of severe multi-fatality events (see also Sect. 5.2). While 2 years had an annual number of deaths greater than 100 , a total of 5 years exceeded the value of 33.2 (mean plus 1 standard deviation). The annual number of events ranged from 1 (in 1995) to 45 (in 1951), with a median over the study period of 7.0 and a mean value of 9.1 (Fig. 2).

The number of people killed by natural hazards in the last 70 years showed a clear decrease over time (Fig. 2). The downward trend in the total number of annual fatalities is statistically significant (Mann-Kendall trend test: 2-sided $p$ value $=<10^{-3}$; Theil-Sen slope estimate: -0.207 deaths per year; R packages kendall and zyp, McLeod, 2015, Bronaugh and Werner, 2009). This pattern is confirmed when the total number of deaths during the first 35 years of the 
Table 1. Natural hazard fatalities in Switzerland (1946-2015) classified by gender. The last column indicates the median altitude at which victims of natural hazards died.

\begin{tabular}{|c|c|c|c|c|c|c|c|c|c|c|c|}
\hline \multirow[b]{2}{*}{ Process type } & \multicolumn{2}{|c|}{ Total fatalities } & $\begin{array}{r}\text { Normalised } \\
\text { fatalities }\end{array}$ & \multicolumn{2}{|c|}{ Female fatalities } & \multicolumn{2}{|c|}{ Male fatalities } & \multirow{2}{*}{$\begin{array}{r}\text { Gender } \\
\text { unknown }\end{array}$} & \multirow{2}{*}{$\begin{array}{r}\begin{array}{r}\text { Percent } \\
\text { female } \\
\text { deaths }\end{array} \\
{[\%]}\end{array}$} & \multirow{2}{*}{$\begin{array}{r}\begin{array}{r}\text { Percent } \\
\text { male } \\
\text { deaths }\end{array} \\
{[\%]}\end{array}$} & \multirow{2}{*}{$\begin{array}{l}\text { Altitude* } \\
\text { [m a.s.1.] }\end{array}$} \\
\hline & [deaths] & {$[\%]$} & [deaths $10^{6}$ cap. $^{-1} \mathrm{a}^{-1}$ ] & [deaths] & {$[\%]$} & [deaths] & {$[\%]$} & & & & \\
\hline Flood & 124 & 12.1 & 0.29 & 31 & 12.8 & 92 & 11.9 & 1 & 25.0 & 74.2 & 559 \\
\hline Landslide & 74 & 7.2 & 0.16 & 33 & 13.6 & 41 & 5.3 & 0 & 44.6 & 55.4 & 820 \\
\hline Rockfall & 85 & 8.3 & 0.20 & 21 & 8.7 & 64 & 8.2 & 0 & 24.7 & 75.3 & 1082 \\
\hline Windstorm & 105 & 10.3 & 0.24 & 25 & 10.3 & 79 & 10.2 & 1 & 23.8 & 75.2 & 431 \\
\hline Lightning & 164 & 16.0 & 0.42 & 33 & 13.6 & 130 & 16.8 & 1 & 20.1 & 79.3 & 692 \\
\hline Avalanche & 378 & 37.0 & 0.96 & 92 & 38.0 & 285 & 36.7 & 1 & 24.3 & 75.4 & 1467 \\
\hline Other & 93 & 9.1 & 0.23 & 7 & 2.9 & 85 & 11.0 & 1 & 7.5 & 91.4 & 2081 \\
\hline All processes & 1023 & 100 & 2.50 & 242 & 100 & 776 & 100 & 5 & 23.7 & 75.9 & 1179 \\
\hline
\end{tabular}

* Note that for snow avalanches only, the altitude of the lowest deposition point was used for technical reasons, which might lead to a slight underestimation in comparison with all other processes.

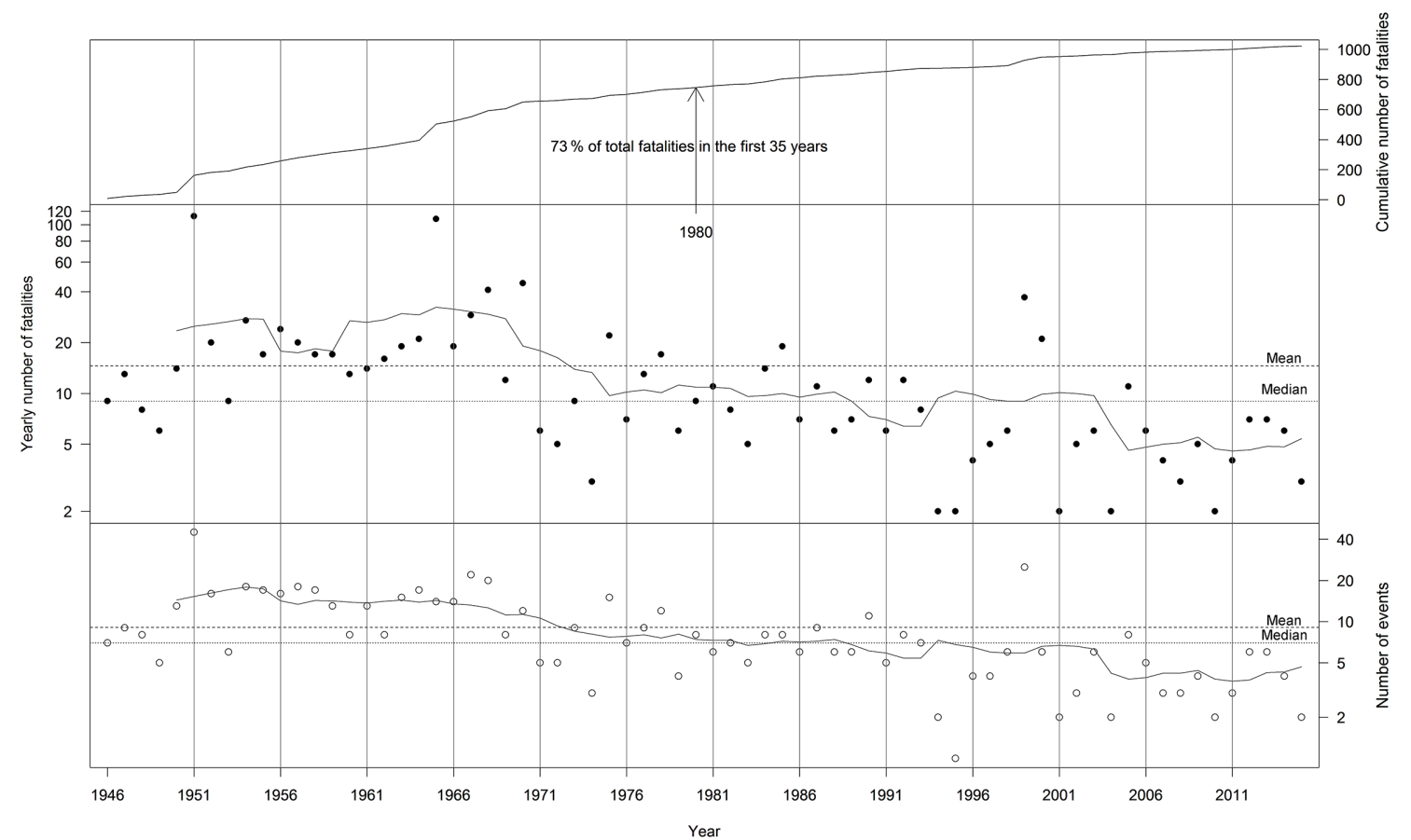

Figure 2. Total number of natural hazard deaths in Switzerland from 1946 to 2015. Cumulative number of fatalities (top) and annual frequency of fatalities (middle). At the bottom of the figure, the number of fatal natural hazard events is displayed. The dashed and dotted horizontal lines in the middle and bottom panels indicate the mean and median annual fatality frequencies and mean and median annual event frequencies, respectively. The thin grey lines in the middle and bottom panels show a 10-year running mean.

study period (747) is compared with the value for the second 35 years (276). Thus, nearly three times as many people were killed by natural hazard processes from 1946 to 1980 than from 1981 to 2015 (Fig. 2). Further, only 3 years after 1981 exhibited a number of fatalities larger than the mean value for the full 70-year period: 1985, 1999 and 2000. The decrease in natural hazard fatalities over the 70-year period is also apparent in the number of fatalities per decade. On average, nearly three times as many people died in accidents during the first three decades of the study period compared to the last four decades.

The temporal distributions of victims of specific hazard types showed a distinct decrease for lightning and avalanches only (Figs. 3 and 4). The trend is statistically significant for avalanches (Mann-Kendall trend test: 2 -sided $p$ value $=<10^{-3}$; Theil-Sen slope estimate: -0.042 deaths per year) and lightning (Mann-Kendall test: 2 -sided $p$ value $=<10^{-3}$; Theil-Sen slope estimate: -0.063 deaths per year). For both process types, around four times as 


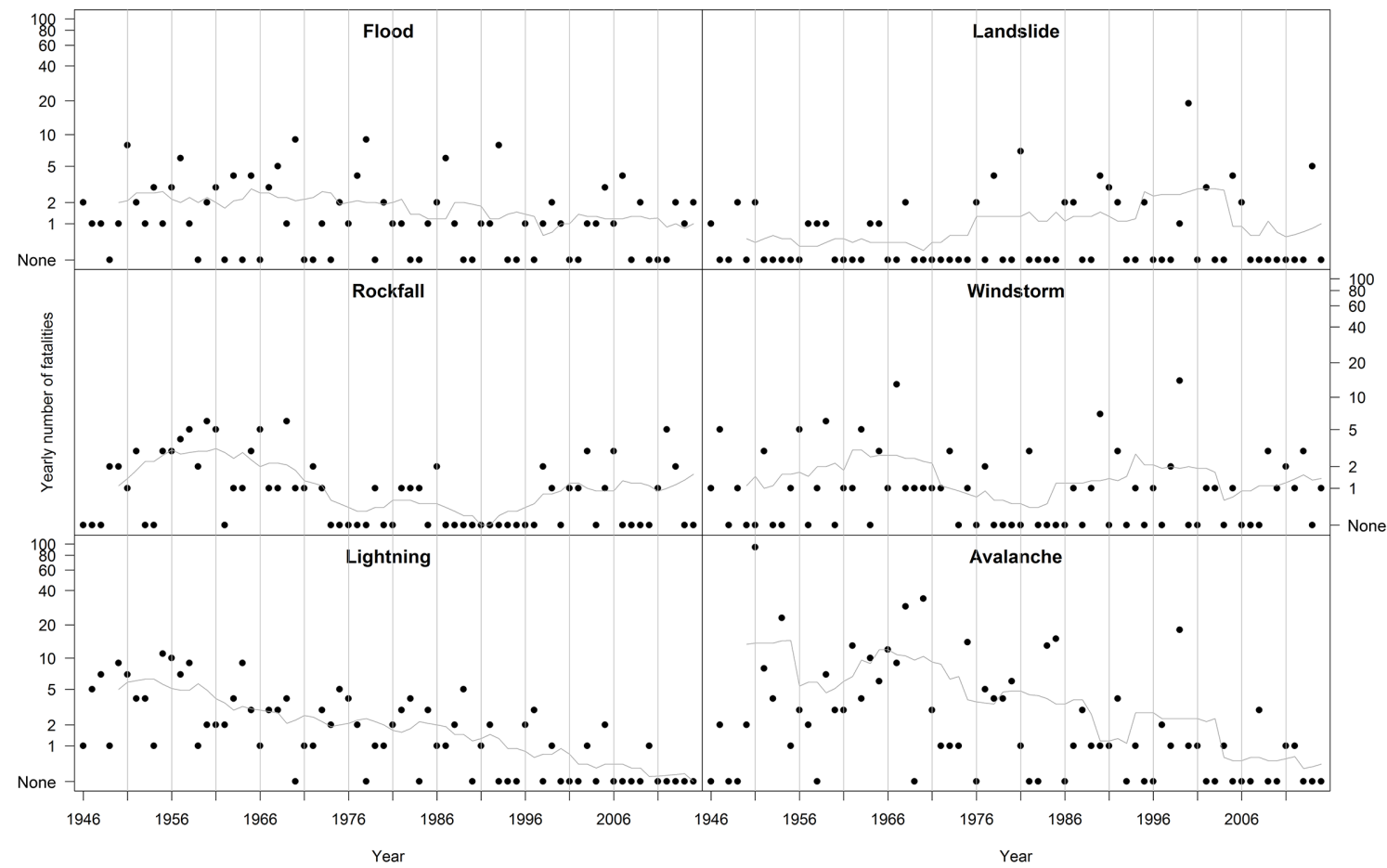

Figure 3. Annual frequency of fatalities in Switzerland for the different natural hazard categories considered in this study (except the category other) from 1946 to 2015 . The thin grey lines in all panels show a 10-year running mean. Note that years with no fatalities were assigned an arbitrary value of 0.5 for plotting purposes and are labelled "none" on the $y$ axis.

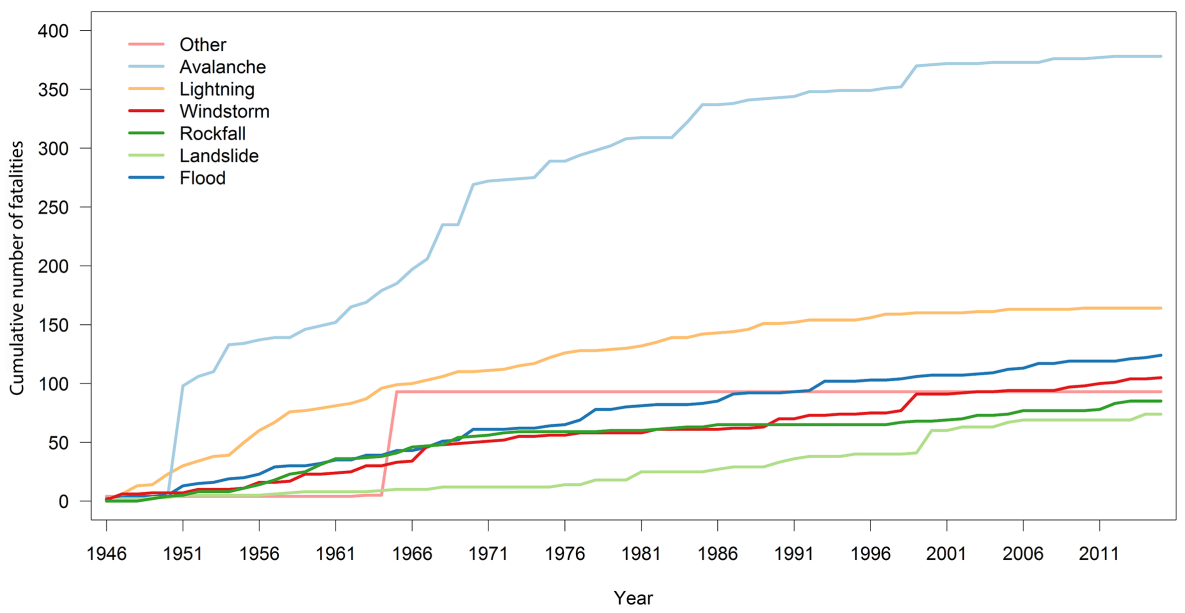

Figure 4. Cumulative plot of the number of natural hazard deaths in Switzerland from 1946 to 2015 for the different natural hazard categories considered in this study.

many fatalities were recorded in the first half of the study period than in the second half (Fig. 4). Interestingly, in the last 15 years, the database revealed only seven avalanche fatalities, resulting in an average for this most recent period that is 10 times smaller than the overall mean value. In a qualitative sense, only deaths due to landslide processes seem to have increased slightly over the 70-year period. However, this impression was strongly influenced by the large number of fa- talities (16) that occurred in the severe 14 October 2000 event in the canton of Valais, when 13 people died in the Gondo landslide.

There were several years in the data set of each natural hazard type when no fatal incidents were reported (Fig. 3). The three hazard types for which at least one fatality was reported in most years of the study period are lightning (49 years), avalanches (48 years) and floods (48 years). 
While at least one fatality associated with windstorm and rockfall events occurred in 40 and 37 years, respectively, fatal accidents related to landslide processes occurred only in onethird of the investigated years. Even though only one deadly ice avalanche happened between 1946 and 2015 (category other processes), this event was responsible for more fatalities than all rockfall or all landslide incidents (Fig. 4).

Normalisation of fatality data by population resulted in a clearly declining annual crude mortality rate. We found an annual average rate of 3.9 deaths per million persons for the first 35 years of the study period and a rate of 1.1 for the second 35 years. The yearly mean for the whole period is 2.5 victims per million persons. A very distinct decrease in the mortality rate from the first to the second half of the study period appears for the processes lightning (0.7 to 0.14) and avalanches (1.63 to 0.29 ), and to a slightly lesser extent for the processes floods ( 0.41 to 0.18 ), rockfall ( 0.31 to 0.10 ) and windstorms ( 0.30 to 0.19$)$.

\subsubsection{Monthly distribution of fatalities}

The monthly distribution of natural hazard fatalities from 1946 to 2015 showed two distinct peaks, one in summer and one in winter (Fig. 5). The first peak was due to the seasonal distribution of classic "summer processes" such as lightning, floods and, to a lesser extent, also landslides and rockfall incidents, which occur most frequently in June, July and August. Additionally, the catastrophic ice avalanche event in 1965 contributed considerably to the establishment of August as the month with most loss of life (207 fatalities). The winter peak was largely caused by avalanches, the most fatal process type in Switzerland, which accounted for 242 of the overall 280 deaths in the months of January (135 avalanche-related deaths out of 145 total deaths) and February (107 avalanche deaths/135 total deaths). The months of March, April and May in spring and September to December in autumn and early winter exhibited relatively low fatality numbers, i.e. below 60 . The month with the fewest deaths relating to natural hazard processes was November, in which a total of 22 deaths occurred over the last 70 years. This corresponds to a fatality number roughly 1 order of magnitude smaller than the value in August.

These seasonal patterns resulted in a high percentage of fatalities in summer (June, July and August; $41.7 \%$ ) and winter (December, January and February; $32.2 \%$ ). In contrast, spring (March, April and May; 16.0\%) and autumn (September, October and November; $10.1 \%$ ) displayed low percentages. While $85.4 \%$ of lightning deaths and $67.7 \%$ of flood deaths occurred in summer, $70.6 \%$ of avalanche victims were killed in winter and $24.9 \%$ in spring. In autumn, only fatalities by landslides show an relatively high percentage $(39.2 \%)$. The temporal distribution of seasonal fatality data (all process types combined) is displayed in Fig. 6 . The plots show a distinct, statistically significant decrease over time for fatalities that occurred in winter (Mann-

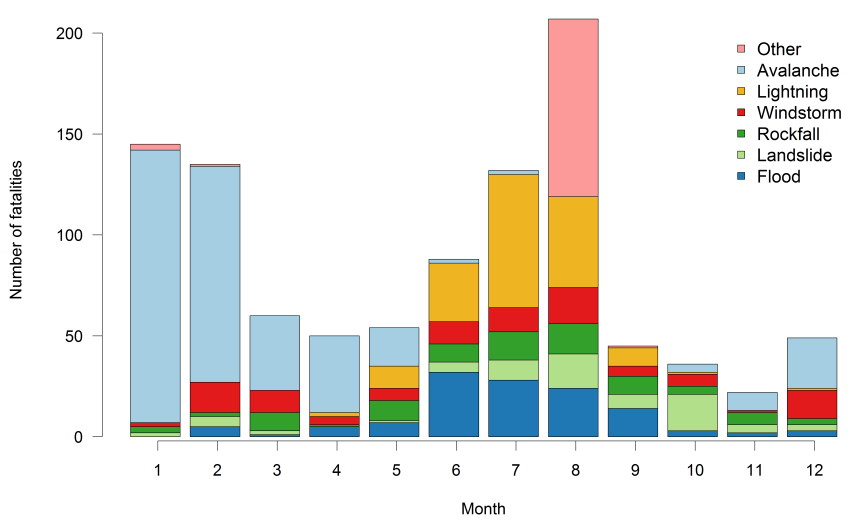

Figure 5. Monthly distribution of natural hazard fatalities in Switzerland from 1946 to 2015 (sum over study period). The different colours indicate the seven process categories defined for this study.

Kendall trend test: 2-sided $p$ value $=<10^{-3}$; Theil-Sen slope estimate: $y=-0.047$ ), spring (Mann-Kendall trend test: 2 -sided $p$ value $=0.002$; Theil-Sen slope estimate: $y=-0.024$ ) and summer (Mann-Kendall trend test: 2-sided $p$ value $=<10^{-3}$; Theil-Sen slope estimate: $\left.y=-0.074\right)$. In contrast, the number of autumn victims has not significantly changed over the study period.

\subsubsection{Natural hazard fatalities classified by time of day}

Based on information on the fatality event time, we assigned the cases to four different time periods: morning (06:0011:59 local standard time), afternoon (12:00-17:59), evening (18:00-23:59) and night (00:00-05:59). Most of the fatalities occurred in the afternoon (39\%), followed by the evening $(23 \%)$, the morning $(17 \%)$ and the night $(11 \%)$. For $10 \%$ of the fatalities, no exact event time could be determined (Fig. 7). Fatalities due to lightning strikes, floods or windstorms occurred mostly in the afternoon and in the evening, whereas no characteristic time period could be distinguished for the occurrence of fatalities due to avalanches, rockfall events and landslides. However, avalanche and landslide processes showed a considerably higher percentage of deaths at night (roughly $20 \%$ ) compared to the other processes (less than $10 \%)$.

\subsection{Spatial distribution of natural hazard fatalities in Switzerland}

Fatalities caused by natural hazard processes were relatively homogeneously distributed over the entire territory of Switzerland (Fig. 8). There are a few, mostly small, areas where very few or even no deaths were found in our data set. This is also visible in Fig. 9, which shows the number of fatalities and events using a $10 \times 10 \mathrm{~km}$ raster grid. Multifatality events were much more frequent in the mountainous 


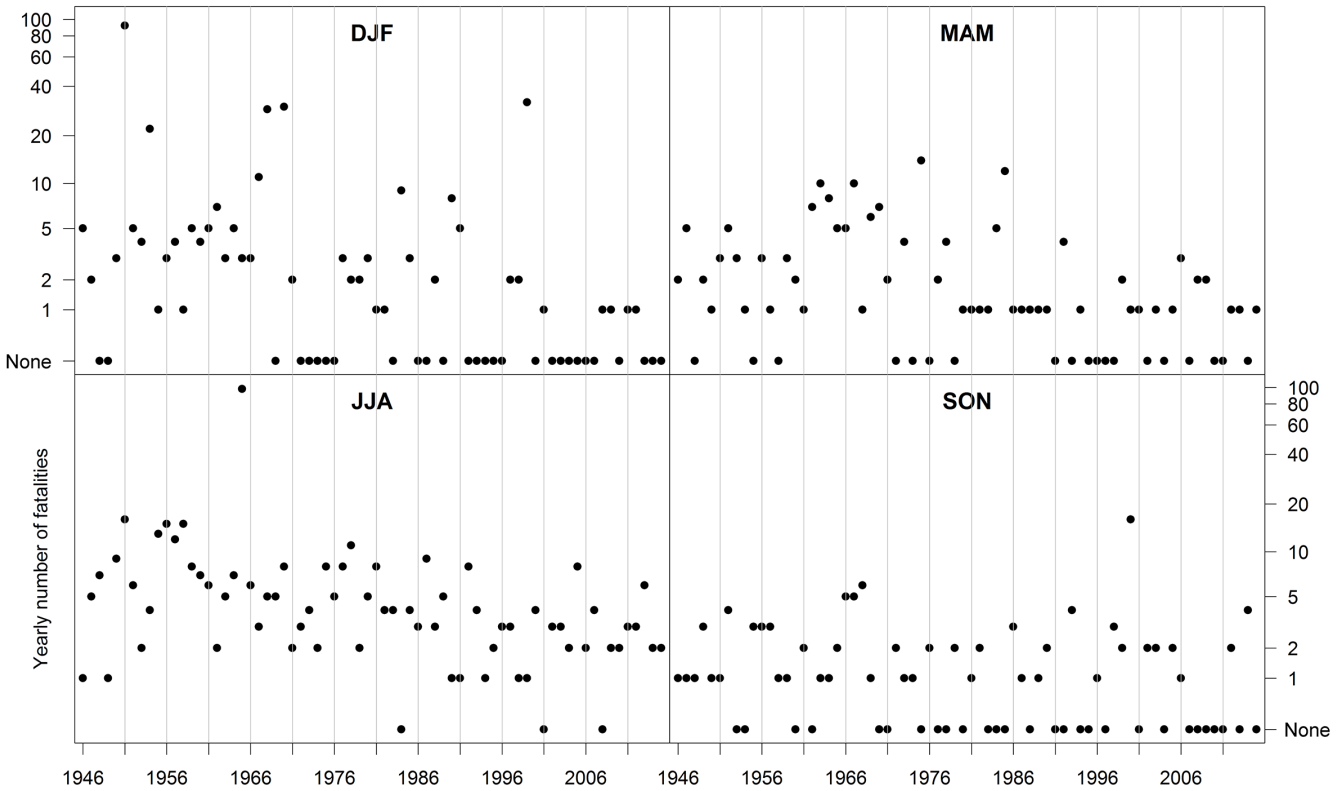

Figure 6. Annual frequency of total natural hazard fatalities in Switzerland from 1946 to 2015 for the four Northern Hemisphere seasons winter (DJF, top left), spring (MAM, top right), summer (JJA, bottom left) and autumn (SON, bottom right). Note that years with no fatalities in a certain season were assigned an arbitrary value of 0.5 for plotting purposes and are labelled "none" on the $y$ axis.

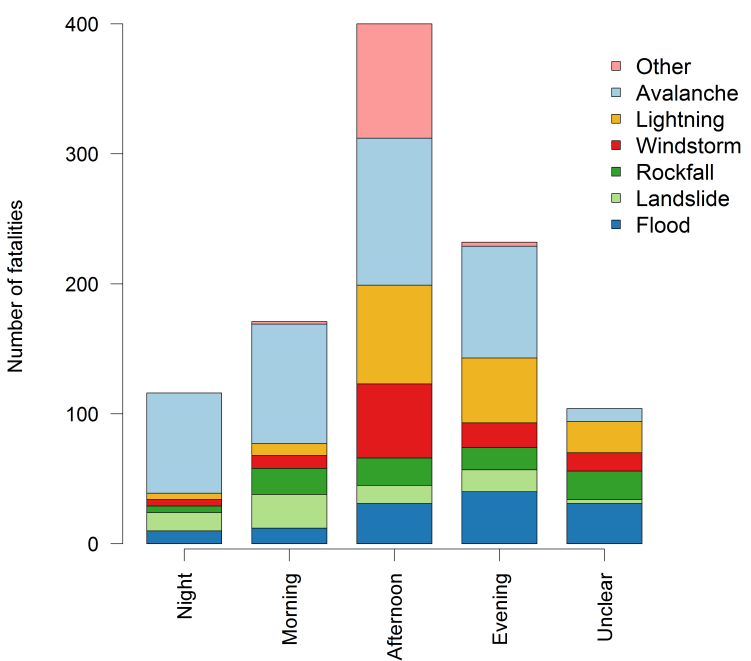

Figure 7. Distribution of natural hazard fatalities in Switzerland from 1946 to 2015 by time of day (sum over study period); morning (06:00-11:59 local standard time), afternoon (12:00-17:59), evening (18:00-23:59) and night (00:00-05:59). The different colours indicate the seven process categories defined for this study.

parts of the country (Alps) compared to the Swiss Plateau and the hilly Jura (Fig. 8).

As can be expected, fatalities resulting from avalanches occurred mainly in the high-Alpine parts of Switzerland (Figs. 8 and $\mathrm{S} 1$ in the Supplement). A few accidents were reported from the western and central Prealps (transitional areas to the high-Alpine part of Switzerland). In contrast, no fa- tal incidents relating to avalanches occurred in the hilly Jura and the Swiss Plateau regions. Clusters are present, e.g. in the area around Andermatt in the southern part of the canton Uri (UR) and around Davos in the canton Grisons (GR). Also, a notably large number of multi-fatality avalanche events is visible in Fig. 8 (see also Sect. 5.2). Interestingly, some mountainous but populated regions showed very few or no deaths by avalanches at all. Such areas are located in several parts of Grisons and Valais (VS), as well as in parts of northern Ticino (TI).

Most of the fatalities caused by landslide processes were recorded in the Alps and Prealps, and a few were documented in the Swiss Plateau (Figs. 8 and S1). The largest number of landslide deaths occurred in the canton Valais, and the worst landslide event in the database (with 13 fatalities) occurred in Gondo (VS) in October 2000. Similar to landslide accidents, fatal rockfall accidents predominantly took place in the central Alps and Prealps, e.g. in the cantons of Valais, Grisons, Vaud (VD) and Uri. A limited number of these fatalities occurred in the Jura and the Swiss Plateau.

Flood fatalities were rather homogeneously distributed over Switzerland and occurred in almost all regions/cantons over the last 70 years (Figs. 8 and S1). Still, there were considerably more cases (some of them multi-fatality incidents) in the Swiss Plateau than in any other Swiss region. The fewest deaths by floods occurred in the region Jura and the canton Valais. Some areas, such as the canton of Neuchâtel (NE), the eastern part of canton Grisons and south-eastern Valais exhibited no flood fatalities at all. 


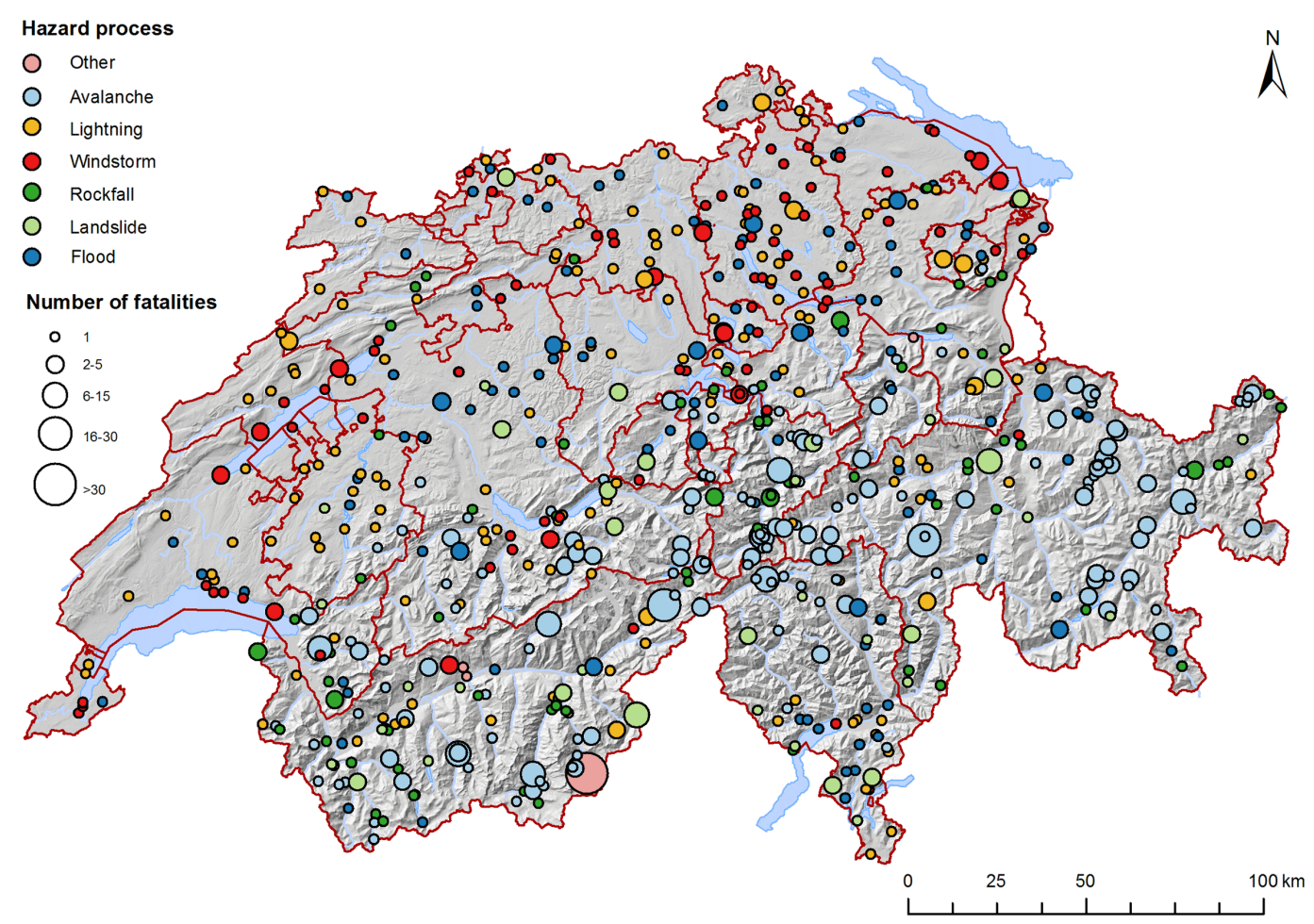

Figure 8. Spatial distribution of fatalities caused during natural hazard events in Switzerland from 1946 to 2015 . The colour of each data point indicates the process category, and the size of the symbol shows the number of deaths per fatal accident (DHM source: dhm $25^{\circledR} 2016$ swisstopo, 5704000 000).

Lightning fatalities occurred all over Switzerland, and by far most of them took place on the Swiss Plateau (Figs. 8 and S1). However, some high-mountain areas in several different parts of Switzerland exhibited very few lightningrelated deaths (e.g. in cantons Grisons, Valais, Uri and Ticino). Windstorm-related fatalities were also mainly registered along the Swiss Plateau. This region exhibited more than half of all windstorm-related fatalities. Some cases occurred in the Jura, the Prealps and on the border of the Alps. In contrast, very few wind-related fatalities occurred in the large Alpine cantons Grisons, Valais and Ticino. Areas around lakes (Lake Zurich, Lake Neuchatel, Lake Geneva, Lake Constance) had clusters of windstorm fatalities due to a considerable number of capsizing accidents.

The spatial distribution of natural hazard fatalities for the different process types was confirmed by the altitude data for each event. For roughly three-quarters of the fatalities, we were able to define the exact altitude at which the victim died (for slightly less than $25 \%$ of the fatalities the accident altitude was estimated). While median altitude was high for avalanche and rockfall victims (1467 and $1082 \mathrm{~m}$ a.s.l., respectively), landslide and lightning victims were killed at intermediate altitudes (820 and $692 \mathrm{~m}$ a.s.l., respectively; Table 1). In contrast, flood and windstorm fatalities were mainly registered at low altitudes representative of the Swiss Plateau (median values of 559 and $431 \mathrm{~m}$ a.s.l., respectively).
By combining the gridded natural hazard fatality data (Fig. 9) with population data (Fig. 10, above), a spatially distributed mortality rate with a $10 \mathrm{~km}$ grid resolution was assessed for all of Switzerland (fatalities per year and per one million persons; Fig. 10, below). Obviously, the weakly populated, high-Alpine areas with avalanche, landslide and rockfall incidents show the grid cells with the highest mortality rates on Swiss territory. A cluster of cells with very high rates is discernible in the central part of the Alps. While in the Prealps high rates are still widespread, the more densely populated Swiss Plateau displays a majority of grid cells with mostly low and some medium mortality rates. The hilly Jura shows a few cells with medium or slightly elevated rates. Grid cells in which fatal natural hazards did occur, but which are not populated due to their position in high-Alpine terrain (in most cases in the immediate vicinity of the country's borders), are indicated in red (Fig. 10, below; Sect. 5.6).

\subsection{Natural hazard fatalities classified by age and gender}

The age of victims was provided for more than $93 \%$ of the natural hazard fatalities reported in our database (954 out of 1023). Overall, the age groups with the highest death toll were the 20-29 year-old (172 fatalities) and 30-39 year-old (177 fatalities) groups, followed by the $40-49$ year-old group 


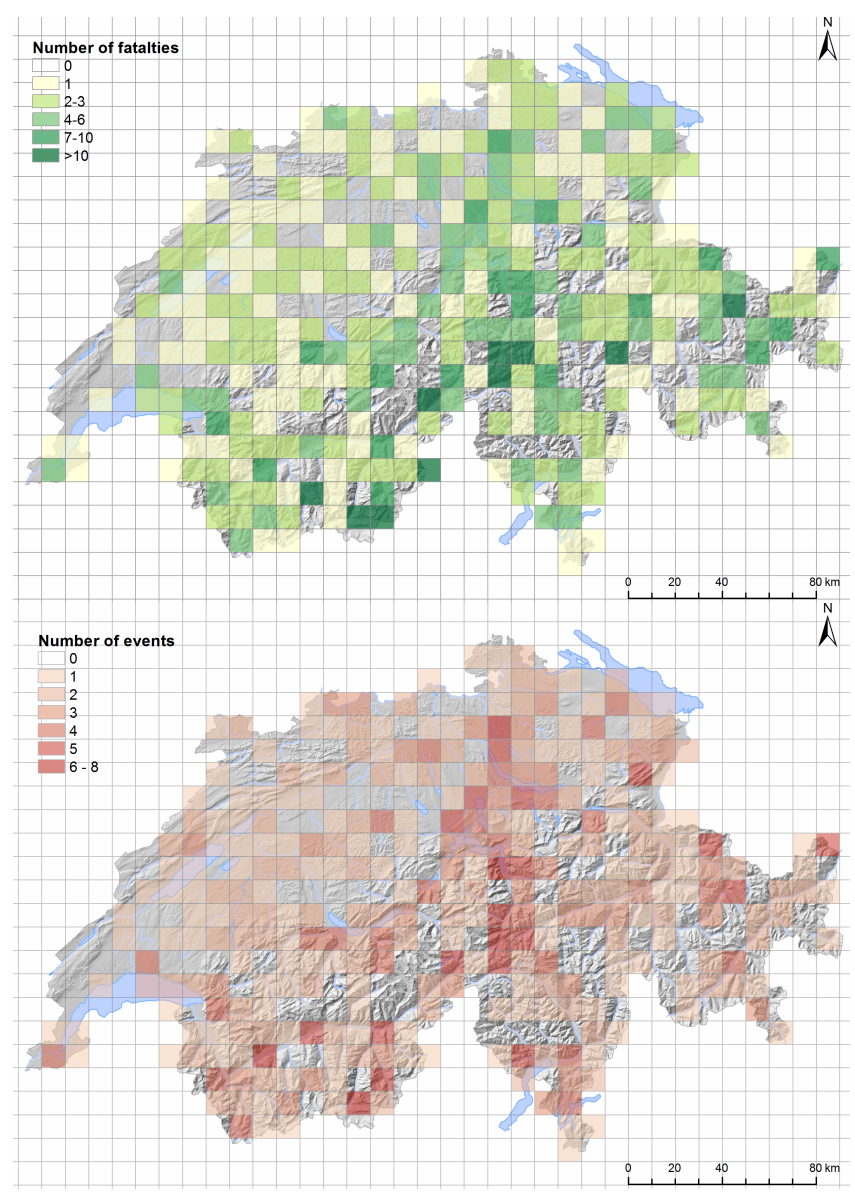

Figure 9. Spatial distribution of natural hazard fatalities (above) and fatal natural hazard events (below) in Switzerland over the 70-year study period using a $10 \times 10 \mathrm{~km}$ raster grid $\left(\right.$ DHM source: $\mathrm{dhm} 25^{\odot}$ 2016 swisstopo, 5704000 000).

with 151 fatalities (Fig. 11, Table S2). These values correspond to a combined 500 victims (or $48.9 \%$ ) between 20 and 49 years of age. While children and teenagers (0-19) accounted for $20.9 \%$ of natural hazard deaths, people above 60 years of age made up only $12.6 \%$.

When focusing on age-related patterns for the individual process types, several discrepancies from the overall numbers attract attention. For example, about one fifth of all flood victims were younger than 10 years of age compared to $7.5 \%$ for all hazard processes (Fig. 11). Most of these very young victims drowned in the first half of the study period. In addition, the percentage of victims over 60 years of age was more than twice as high for flood fatalities $(25.8 \%)$ as for all fatalities. Lightning rarely killed young children $(2.4 \%$ in the $0-9$ year-old age group) but seems to particularly affect teenagers. The 10-19 year-old age group constituted $23.2 \%$ of all lightning victims, which is much higher than the value for all processes $(13.4 \%)$. The large majority of these teenagers were killed in the first part of our investigation period. Finally, windstorm victims below 20 years of age

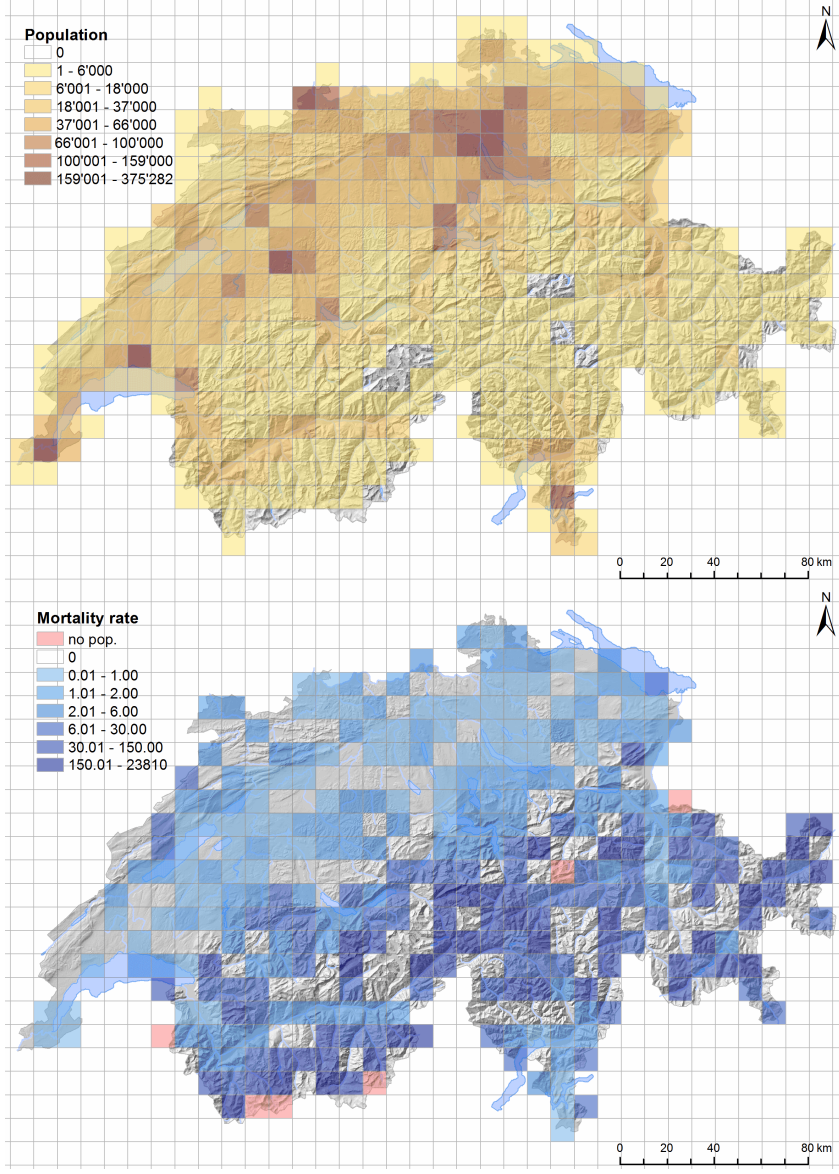

Figure 10. Spatial distribution of the population as of 2015 (above) and normalised natural hazard fatalities per year and million population (below) in Switzerland over the 70-year study period using a $10 \times 10 \mathrm{~km}$ raster grid (DHM source: $\mathrm{dhm} 25^{\circledR} 2016$ swisstopo, 5704000 000). Note that the gridded mortality rate (below) represents a rough estimate because the population data of 2015 were used for its calculation (prior data not available in this format). Also, note that no mortality rate was calculated for the red grid cells because they are not populated (even though fatalities occurred there)

were underrepresented $(10.5 \%)$ compared to the full data set $(20.9 \%)$.

Gender was provided for practically all $(99.5 \%)$ natural hazard fatalities in our database. Summarised for all process types, more than three-quarters of all natural hazard victims were male, indicating that males were approximately three times as likely to become fatality victims as females (Table 1). Male fatalities greatly outnumbered female deaths for every process category (percentage of male fatalities between 74.2 and $79.3 \%$ ), with the exception of landslides and processes in the other category (including ice avalanches) (Fig. 11). While the proportions of male and female victims of landslides were quite similar (55.4 and $44.6 \%$, respectively; Table 1), the victims killed by the ice avalanche of 1965, which destroyed a dam construction site, were practi- 


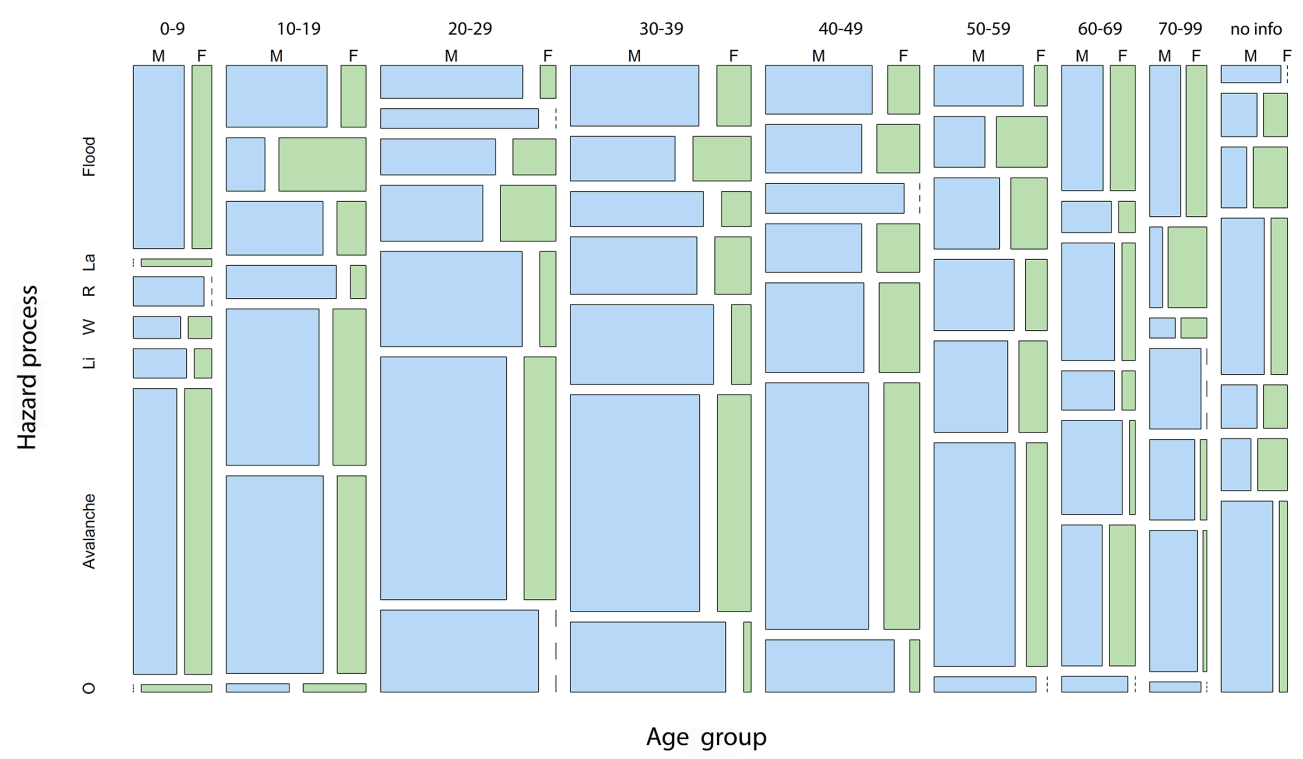

Figure 11. Mosaic plot showing age groups and gender ( $M$ is male, $F$ is female) for natural hazard fatalities in Switzerland (1946-2015). Fatalities are subdivided according to the hazard category (flood, La is landslide, $\mathrm{R}$ is rockfall, $\mathrm{W}$ is windstorm, $\mathrm{Li}$ is lightning, avalanche and $\mathrm{O}$ is other). Also see Table S2.

cally all males (96.6\%). Expressed differently, female landslide deaths represented $13.6 \%$ of all female natural hazard fatalities, whereas the same value for males was only $5.3 \%$. Correspondingly, processes classified as other were the cause of death in $11.0 \%$ of male victims in our records, while this value was negligible for female victims $(2.9 \%)$.

Regarding the ages of victims, the number of male victims in natural hazard fatalities was considerably larger than the number of female fatalities within every age group (Fig. 11). This pattern is accentuated for young adults between 20 and 39 years of age, of which the percentage of male victims was more than $80 \%$, whereas for young children from 0 to 9 years of age the percentage of female victims was highest at $34 \%$. Accordingly, the age distribution of male and female victims of natural hazard processes exhibits a few differences. Whereas $26.4 \%$ of female fatalities were younger than 20 years of age, this applied to only $19.4 \%$ of male victims (Table S2). In contrast, the percentage of young adult victims between 20 and 39 years of age was much higher for males (37.2\% of all deaths) than for females $(25.2 \%)$.

\subsection{Natural hazard fatalities in different accident circumstances}

Accident circumstances, such as activity (work or leisure time), locality (on transportation routes, in open terrain, in or around buildings, on a lake, in the immediate vicinity of a stream channel) and mode of transportation (on foot, in a vehicle, on a boat, on skis, on a bicycle, in public transport) were analysed for the 1023 entries in our database (Fig. 12, Table 2). Regarding victim activity, we found that $52 \%$ of all fatalities occurred during leisure time, $35 \%$ occurred during work, and the activity could not be assigned in $13 \%$ of the cases. The assessment of incident locality revealed that most of the fatalities occurred on transportation routes (33\%), in open terrain $(14 \%)$ or in or around buildings (home $20 \%$, other buildings $6 \%$, around buildings $3 \%$ ). For all fatalities except those in buildings, the mode of transport was determined: $62 \%$ of victims were killed while on foot, $18 \%$ in a vehicle, $7 \%$ on a boat, $6 \%$ on skis, $1 \%$ in public transport and less than $1 \%$ on a bicycle.

Avalanches killed more than twice as many people during leisure time (245) as during work (110). People killed by avalanches during work were mostly located on transportation routes (72), mainly travelling by foot (35) or in vehicles (16). People who died in avalanches during leisure time were usually at home (159) or were travelling on transportation routes (83). Similarly, for floods, windstorms, landslides and rockfall events, fatalities that occurred during leisure time were at least twice as frequent as those that occurred during work. The hazard event with the largest number of people killed during work was the ice avalanche in Mattmark with 88 deaths (category other). People fatally struck by lightning were working in $43 \%$ of the cases (Table 2).

Most victims of floods were killed in the stream channel sector (63) and were usually carried along by the high water. Flood-related fatalities on transportation routes were also relatively common (31), with 11 victims travelling in vehicles, 16 by foot, 2 by bicycle, 1 in public transport and in one case it was unclear. Regarding windstorm-related incidents, most of the fatalities occurred on lakes with victims in boats (44). Thirty-four windstorm-related fatalities occurred on transportation routes, in which 20 victims were killed in vehicles, 

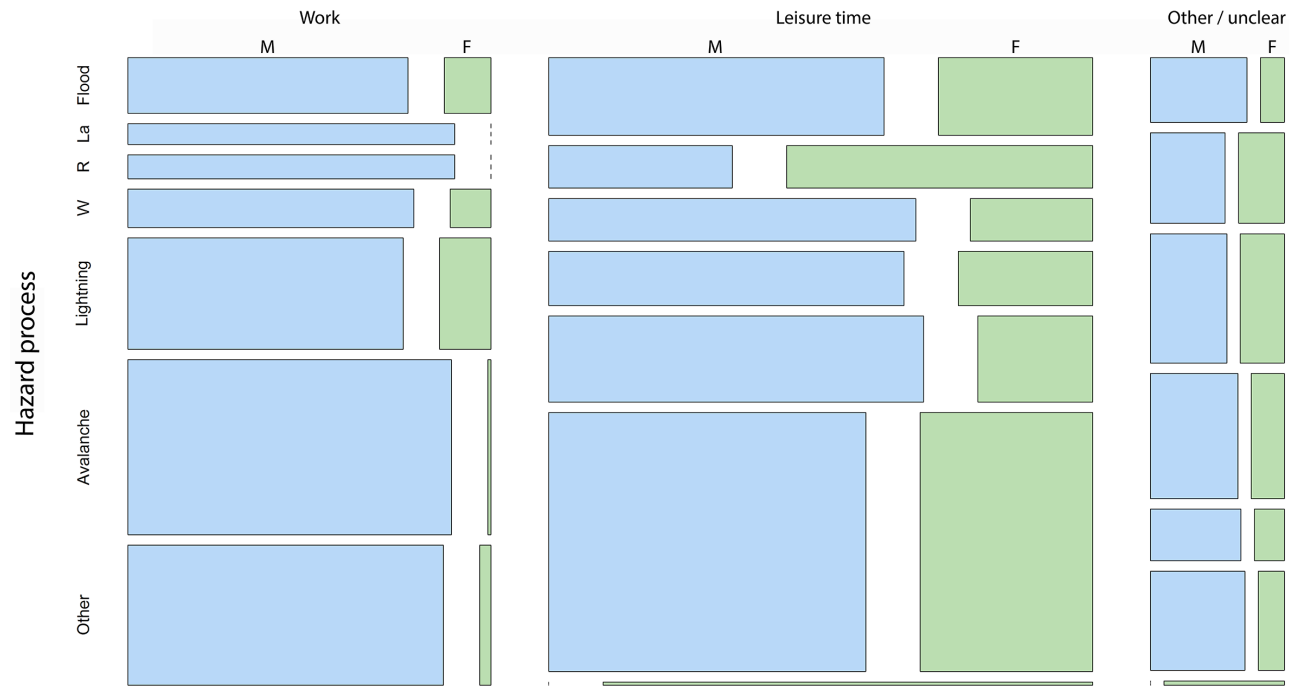

Activity

Figure 12. Mosaic plot showing the activity and gender of victims ( $M$ is male, $F$ is female) for natural hazard fatalities in Switzerland (19462015). Fatalities are subdivided according to the hazard category (flood, La is landslide, $\mathrm{R}$ is rockfall, $\mathrm{W}$ is windstorm, lightning, avalanche and other). Also see Table 2.

Table 2. Natural hazard fatalities in Switzerland (1946-2015) classified by activity, accident locality and mode of transport.

\begin{tabular}{|c|c|c|c|c|c|c|c|c|c|c|}
\hline & & Flood & Landslide & Rockfall & Windstorm & Avalanche & Lightning & Other & All processes & All processes [\%] \\
\hline \multirow{4}{*}{ 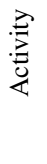 } & work & 35 & 13 & 15 & 24 & 110 & 70 & 88 & 355 & 34.7 \\
\hline & leisure time & 73 & 40 & 40 & 52 & 245 & 82 & 4 & 536 & 52.4 \\
\hline & other/unclear & 16 & 21 & 30 & 29 & 23 & 12 & 1 & 132 & 12.9 \\
\hline & total & 124 & 74 & 85 & 105 & 378 & 164 & 93 & 1023 & 100 \\
\hline \multirow{7}{*}{ 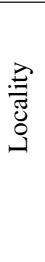 } & in or around a building & 14 & 40 & 8 & 4 & 192 & 33 & 2 & 293 & 28.6 \\
\hline & on transportation routes & 31 & 20 & 58 & 34 & 164 & 28 & 1 & 336 & 32.8 \\
\hline & in open terrain & 4 & 11 & 14 & 9 & 4 & 95 & 1 & 138 & 13.5 \\
\hline & on a lake & - & - & 1 & 44 & - & 1 & - & 46 & 4.5 \\
\hline & in a stream channel & 63 & 2 & - & - & - & - & - & 65 & 6.4 \\
\hline & other/unclear & 12 & 1 & 4 & 14 & 18 & 7 & 89 & 145 & 14.2 \\
\hline & total & 124 & 74 & 85 & 105 & 378 & 164 & 93 & 1023 & 100 \\
\hline \multirow{8}{*}{ 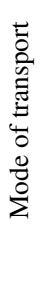 } & on foot & 77 & 22 & 51 & 36 & 78 & 112 & 90 & 466 & 61.6 \\
\hline & in vehicle & 20 & 11 & 27 & 20 & 46 & 14 & - & 138 & 18.2 \\
\hline & by boat & 5 & - & - & 44 & - & 1 & - & 50 & 6.6 \\
\hline & by ski & - & - & - & - & 49 & - & - & 49 & 6.5 \\
\hline & by bicycle & 3 & - & - & 1 & - & 6 & - & 10 & 1.3 \\
\hline & by public transport & 1 & 1 & - & - & 4 & - & - & 6 & 0.8 \\
\hline & other/unclear & 9 & - & 2 & 4 & 16 & 5 & 2 & 38 & 5.0 \\
\hline & total $^{*}$ & 115 & 34 & 80 & 105 & 193 & 138 & 92 & 757 & 100 \\
\hline
\end{tabular}

* Note that 266 fatalities that occurred in buildings are not considered in this section (mode of transportation).

13 on foot and 1 on a bicycle. Loss of life caused by landslide processes occurred mostly in and around buildings (40). Twenty people were killed by landslides while on transportation routes, and 11 of these victims were in vehicles, 8 on foot and 1 in public transport. Most people killed by rockfall were on transportation routes (58), of which 30 people were travelling by foot and 27 in a vehicle (one unclear), whereas 14 people were killed by rockfall on open terrain. Most of the lightning fatalities occurred on open terrain (95 victims, of which 90 were moving by foot), in or around buildings (33) or on transportation routes ( 28 victims, of which 13 were travelling by foot, 10 in or on a vehicle and 5 by bicycle; Table 2). 


\section{Discussion}

\subsection{Data quality}

\subsubsection{Completeness of the data set}

Several factors influenced the integrity of our data set. (i) Fatal accidents caused by natural hazard processes during the 70 -year study period could simply not have been reported in the Neue Zürcher Zeitung (NZZ) or in the additional data sources used. (ii) The NZZ is a German-language newspaper. The coverage of the news includes all parts of Switzerland (e.g. regarding severe natural hazard events), but there might be a bias towards an underreporting in the other language regions (French, Italian, Romansh), which represent roughly one-third of the population. (iii) For practical reasons, we had to apply a limited number of keywords in our search. Thus, we could have missed reports on natural hazard fatalities in the data sources because our keywords were not used in a particular news source. (iv) There were a few small data gaps in our main data source. Some issues of the NZZ were not present in the data portal applied; hence, we possibly missed fatalities that occurred during such periods. (v) The NZZ archive was established by scanning all newspaper issues and applying a character recognition programme (with the exception of all new editions available digitally since 1994). This procedure is susceptible to errors whenever the character recognition fails due to insufficient scan quality. We encountered this problem when searching for keywords in the first few decades of the study period, mainly for long keywords. (vi) Finally, media articles sometimes mix up technical terms and thus hazard processes (a problem already discussed in Badoux et al., 2014). For example, we suspect that several fatal debris flows were not exactly identified as such in the media during the first few decades of the study period because this process was not yet commonly understood.

All in all, we acknowledge that our database is not fully complete for the time period between 1946 and 2015 and that we might have missed a certain number of natural hazard deaths, mainly in the first decades of our study period. Taking into account our success rate for the validation period (see Sect. 3.3), we are confident that we passed over considerably less than $10 \%$ of the fatalities that occurred. There are two main reasons for this. First, approximately $37 \%$ of all fatalities in the data set presented here were caused by snow avalanches. Because the destructive avalanche database is considered complete for fatality data, less than two-thirds of our data are subject to underestimation. Second, grave events with several deaths are normally described in numerous articles that span over a couple of days or even a few weeks (some incidents are even mentioned in subsequent years for commemoration or retrospection). It is thus very unlikely that we did not register at least one article on a multi-fatality event. Hence, we believe that our database is valuable in its present state.

\subsubsection{Quality of the data}

The quality of our natural hazard fatality data was assessed by considering the levels of uncertainty associated with the incident characteristics and circumstances. In general, uncertainty was low (Table 3). This finding applies primarily to the dates of events, the victims' genders and ages and the locality of the incident (data were labelled as certain in $88 \%$ or more of the cases). Exact reporting of the time an incident occurred was often lacking, and we had to estimate the event time for more than one-third of the fatalities. Data were unavailable in more than $10 \%$ of the cases only for the variables event time and victim activity. Finally, data quality increased in the course of our study period, in that all variables except one (victim activity) show lower uncertainty for the sub-period between 1981 and 2015.

\subsection{The impact of multi-fatality events}

A total of 635 natural hazard events with fatal consequences occurred in Switzerland during the study period (Table 4). The most common situation observed in the last 70 years was for one victim to be killed in a natural hazard incident. Roughly $50 \%$ of the total number of victims lost their lives in one of the 507 single-fatality events recorded in the database. While incidents with two or three fatalities occurred 73 and 25 times, respectively, 25 incidents registered four to $10 \mathrm{fa}$ talities. Only five events caused more than 10 deaths each, resulting in a combined $15.7 \%$ of the total number of victims in the entire study period (Table 4).

The largest of those five events was the Mattmark ice avalanche of 1965 that killed 88 people. The second and third worst multi-fatality events were both snow avalanches. The first of these avalanches occurred in February 1970 in Reckingen (canton of Valais) and represents one of the largest avalanche disasters in the Alps of the 20th century (30 deaths). Among other damage, the avalanche destroyed a Swiss army barrack and residential buildings, killing 19 officers and 11 civilians. The latter incident with 19 deaths occurred in January 1951 in Vals (canton of Grisons) during the worst avalanche winter in Swiss history (Figs. 3 and 4).

Regarding the relative importance of single-fatality events, we detected two distinct categories of natural hazard process types. Flood, rockfall, windstorm and lightning incidents with one victim were responsible for more than $70 \%$ of the total fatalities associated with each of these process types. This value was much smaller for avalanches $(26.2 \%)$ and landslides $(31.1 \%)$ (Table 4$)$. This distinction is probably related to the fact that victims of both avalanche and landslide process types are more often killed in buildings (around $50 \%$ of all cases) than victims of other hazard processes. Affected buildings are likely to be occupied or inhabited by more than one person; thus multi-fatality events are more frequent for avalanches and landslides. Lightning was associated with the highest percentage of deaths in single-fatality 
Table 3. Quality of the data describing the circumstances of fatal natural hazard events and the victims (certain means that information regarding this variable is fully reliable; probable means information regarding this variable was deduced but is very probable; unknown means that no information was available).

\begin{tabular}{lrrrrrr|r}
\hline & Certain & \multicolumn{2}{c}{ Probable } & Unknown & Total \\
\cline { 2 - 7 } & [no. of deaths] & [\%] & [no. of deaths] & [\%] & [no. of deaths] & [\%] & [no. of deaths] \\
\hline Date of event & 965 & 94.3 & 58 & 5.7 & 0 & 0.0 & 1023 \\
Time of event & 558 & 54.5 & 360 & 35.2 & 105 & 10.3 & 1023 \\
Gender & 1015 & 99.2 & 3 & 0.3 & 5 & 0.5 & 1023 \\
Age & 938 & 91.7 & 16 & 1.6 & 69 & 6.7 & 1023 \\
Activity & 788 & 77.0 & 107 & 10.5 & 128 & 12.5 & 1023 \\
Locality & 898 & 87.8 & 101 & 9.9 & 24 & 2.3 & 1023 \\
Mode of transportation * & 541 & 71.5 & 181 & 23.9 & 35 & 4.6 & 757 \\
\hline
\end{tabular}

* Note that 266 fatalities that occurred in buildings are not considered in this row (mode of transportation).

Table 4. Fatal natural hazard events in Switzerland (1946-2015) classified by number of victims. The last two columns indicate the percentage of people that died in single fatality events (second to last column) and in events with more than 10 deaths (last column); note that in the bottom row $100 \%$ corresponds to 1023 deaths for all process types.

\begin{tabular}{|c|c|c|c|c|c|c|c|c|}
\hline & \multicolumn{5}{|c|}{ Number of events with $n$ deaths } & \multirow{2}{*}{$\begin{array}{r}\text { All fatal } \\
\text { events }\end{array}$} & \multirow{2}{*}{$\begin{array}{r}\text { Percent of people } \\
\text { killed in events } \\
\text { where } n=1\end{array}$} & \multirow{2}{*}{$\begin{array}{r}\text { Percent of people } \\
\text { killed in events } \\
\text { where } n>10\end{array}$} \\
\hline & $n=1$ & $n=2$ & $n=3$ & $4 \leq n \leq 10$ & $n>10$ & & & \\
\hline & & & & & & & {$[\%]$} & [\%] \\
\hline Flood & 97 & 9 & 3 & - & - & 109 & 78.2 & 0.0 \\
\hline Landslide & 23 & 13 & 2 & 1 & 1 & 40 & 31.1 & 17.6 \\
\hline Rockfall & 68 & 4 & - & 2 & - & 74 & 80.0 & 0.0 \\
\hline Windstorm & 74 & 10 & 1 & 2 & - & 87 & 70.5 & 0.0 \\
\hline Lightning & 144 & 10 & - & - & - & 154 & 87.8 & 0.0 \\
\hline Avalanche & 99 & 27 & 18 & 20 & 3 & 167 & 26.2 & 15.9 \\
\hline Other & 2 & - & 1 & - & 1 & 4 & 2.2 & 94.6 \\
\hline All processes & 507 & 73 & 25 & 25 & 5 & 635 & 49.6 & 15.7 \\
\hline
\end{tabular}

events in Switzerland $(87.8 \%)$. This value is only slightly lower than percentages reported for the USA $(90.9 \%$, Curran et al., 2000) and Australia (92\%, Coates et al., 1993).

\subsection{Evolution of fatality numbers during the last 70 years}

General attempts to explain the decrease in natural hazard fatalities observed in other countries and globally have been made previously. For example, Goklany (2007) indicated that societies' collective adaptive capacities lead to reduced mortality rates due to extreme weather. For the USA, Curran et al. (2000) attributed a decline in lightning-related deaths over time to improved medical care, emergency communication and transportation, as well as better awareness of the serious threat posed by lightning. Improved forecasting, process detection and warning systems may have also contributed to the decrease in fatalities (Curran et al., 2000; López and Holle, 1996). Furthermore, fewer people currently work in open fields than in the past (Elsom, 2001). With the expansion of urban areas more people are spending a greater proportion of their time inside lightning-safe structures compared to previous decades (e.g. Curran et al., 2000; Holle, 2016). These points also apply to Switzerland, which is confirmed by significant decreases in lightning fatalities in particular and total fatalities more generally.

A significant reduction in avalanche fatalities in settlements and on transportation corridors since the 1970s has been noted throughout the countries of the European Alps (e.g. Techel et al., 2016), as well as in other developed regions like Scandinavia (Kristensen, 1998) and North America (e.g. Page et al., 1999; Jamieson et al., 2010). Explanations for this decrease, also detected in our data set for Switzerland, include (i) large investments into permanent avalanche defence structures, which reduce the potential for catastrophic avalanches (e.g. SLF, 2000); (ii) hazard mapping and risk assessment to evaluate appropriate measures for the protection or closure of avalanche-threatened sections of roads in winter (e.g. Wilhelm, 1997; Margreth et al., 2003); (iii) the preventive artificial release of avalanches (e.g. 
Stoffel, 2001); (iv) the improved avalanche education of local authorities responsible for avalanche safety (e.g. Bründl et al., 2004) and (v) an improved and more widely distributed avalanche forecast (Etter et al., 2008).

Many fatalities related to floods and inundations occur because people act imprudently and put themselves in dangerous situations. We assume that a substantial proportion of all flood deaths in our data set can be ascribed to such inappropriate behaviour. For example, they may occur outdoors, when victims are carried away by floodwaters because they were standing too close to a channel, or inside a building, when victims intend to save belongings from flooded basements or when they try to drive vehicles out of inundated underground car parks (see also Sect. 5.5). Similar observations were made abroad, e.g. in association with the use of motor vehicles, when people decided to cross floodwaters, often underestimating the depth and force of flowing water and thus taking significant risks (e.g. FitzGerald et al., 2010; Diakakis and Deligiannakis, 2013). Hence, although Swiss flood protection has been developed and refined considerably in the last decades (e.g. BWG, 2001), implying large financial investments, fatal events can only be prevented by such measures to a limited extent. This could partly explain the relatively moderate decrease in flood fatality over our study period. However, it has to be taken into consideration that deaths caused by floods were dramatically reduced since the middle of the 19th century in Switzerland, as shown, for example, in Petrascheck (1989). Still, it will be very important in the future to better inform and train people who regularly stay in or close to flood prone areas. A similar recommendation could be made for windstorms, as fatalities related to these events also often occurred due to negligent behaviour in dangerous situations.

\subsection{Demography of fatality data}

Our study revealed that male natural hazard fatalities have been much more frequent than female fatalities $(75.9 \%$ male vs. $23.7 \%$ female). This pattern has also been observed in other countries, for example for fatal flood (Ashley and Ashley, 2008; Coates, 1999) and lightning (Singh and Singh, 2015; Navarrete-Aldana et al., 2014; Elsom, 2001; Curran et al., 2000) victims. To explain this striking gender difference, we first need to focus on work-related deaths, which represent slightly more than one-third of all recorded fatalities (Fig. 12, Table 2). A remarkable $93.5 \%$ of all natural hazard victims killed at work were men, and this percentage was at least $95 \%$ in the four first decades of the study period. This finding is probably mainly due to the fact that (i) during the study period, the ratio of men working full time was considerably higher than the ratio of women working full time, especially in the first half of the period, and (ii) many accidents were associated with occupations that are physically demanding and thus were, and to some extent still are, almost exclusively carried out by men, such as farm labour, forestry work, construction work, road maintenance (e.g. snow clearing) and rescue services. Thus, men have been more involved than women in employment (often involving outdoor work) that puts them at risk of dying in a natural hazard event.

More than half of all fatalities in our data set occurred during leisure time (Fig. 12). Of these 536 victims, approximately two-thirds were men and one-third were women. Clearly, the predominance of male fatalities was not as strong as that observed in work-related accidents, but it was still considerable. We assume that the gender difference observed for fatalities during leisure time activities was due to the higher risk perception of women compared to men (e.g. Bubeck et al., 2012; Lindell and Hwang, 2008; Tekely-Yesil et al., 2011). This effect probably leads to a more cautious and less adventurous behaviour of women, which could explain the difference between the number of male and female fatalities. What applies to recreational activities might also be valid for work and it seems that men have an overall greater disposition towards risk-taking than women. For example, this is confirmed by Jensenius (2014) for lightning deaths in the USA. However, a growing recognition of the equality of the genders has led to a greater proportion of women being at risk relative to men (Coates, 1999). This trend is somewhat supported by our data, in that $55.6 \%$ of all leisure time fatalities in the last decade of the study period involved women.

\subsection{Effects of location, mode of transport, activity and inappropriate behaviour}

The percentage of people who drowned in vehicles was much smaller in Switzerland (16\% of all flood victims) compared to values reported in studies of other countries. For example, $77 \%$ of flood fatalities were vehicle related in a study from the US state of Texas (Sharif et al., 2015), and $63 \%$ were vehicle related in a study of the USA as a whole (Ashley and Ashley, 2008). It was suggested that this large number of fatalities occurs because people incautiously try to cross rivers in their vehicles (Sharif et al., 2015). Most of the people in our study were killed while travelling on foot $(62 \%)$. This percentage includes people who accidentally fell, were swept into the floodwaters or tried to walk through the floodwaters. We assume that most of these fatalities occurred because of inappropriate behaviour and underestimation of risk and thus could have been prevented. The same could be said for the lightning deaths in our study. In most cases, the danger was underrated (e.g. people were struck while working in open fields) or people used inadequate shelter (e.g. under trees). For fatalities due to lightning, a clear trend over time away from outdoor worker casualties towards recreational accidents was apparent in our data set and has also been observed elsewhere (López et al., 1995; Coates et al., 1993). Inappropriate behaviour also led to many of the deaths related to windstorm events. Here, most fatalities occurred on lakes due to capsized boats, when the victim(s) underestimated the heavy winds. Further, many victims were struck by falling 
(parts of) trees or other material that was swirling through the air. Regarding avalanche incidents, most of the fatalities in our database occurred in buildings $(185,49 \%)$ because we excluded deaths due to sports like ski touring and out-ofbounds (off-piste) riding. We assume victims killed in buildings thought they were safe, as the specific damage threshold of buildings is comparably high. However, once this threshold is exceeded during an event, statistics show a high mortality rate for people located in a building (Wilhelm, 1997). Similarly, in the landslide process category, most of the fatalities occurred in buildings (54\%), suggesting that the inhabitants were not expecting an event and were unable to escape from the threat.

\subsection{Comparison of Swiss natural hazard fatality data with data from abroad}

The EM-DAT International Disaster Database is a free and searchable source of information on worldwide victims of natural disasters (EM-DAT, www.emdat.be). In that database, we found 21 database entries for Switzerland in our study period and 329 fatalities associated with natural hazard processes that were considered in our study. Avalanche events led to most of the fatalities recorded in EM-DAT (275), followed by storms (24), landslides (20) and riverine floods (10). A considerable difference from our overall results exists because EM-DAT focuses only on large catastrophic events with at least 10 fatalities, 100 affected people, a call for international assistance or the declaration of a state of emergency. This leads to an underestimation of total fatalities, a problem also stated by Petley (2012). Furthermore, this issue causes an underappreciation of natural hazard processes with a high percentage of single-fatality events (Table 4).

Worldwide, EM-DAT registered a total of 5 million fatalities, including those due to earthquakes (1.51 million, $30.1 \%$ ), mass movement (0.06 million, $1.2 \%$; including landslides, avalanches, rockfall and subsidence), floods (2.48 million, $49.2 \%$ ) and storms (0.98 million, $19.5 \%)$ for the period of 1946 to 2015 . Normalised by population, this results in a mean yearly mortality rate of 19 victims per million people (earthquakes 4.6, floods 11.4, mass movements 0.2 , storms 3.2). This rate is much higher compared to the average annual mortality rate determined in our study for Switzerland (overall 2.5 fatalities per million population and year; flood 0.29 , landslide 0.16 , rockfall 0.20 , storm 0.24 , lightning 0.42 , avalanche 0.96 , category other 0.23 ; Table 1 ).

With the different data collection methods in mind, explanations for these differences could be that most events that occurred in Switzerland during our study period did not cause more than 10 fatalities (all but five events; Table 4). Due to the geographical location of the study area, some very deadly hazard processes, such as tropical storms, did not occur. Further, even though severe earthquakes are possible in Switzerland and have been observed historically, only three such fatalities (all in 1946) were registered. Furthermore, Switzerland exhibits a considerable network of protection measures and a well-developed risk management system (see Sect. 5.3). These tactics probably additionally help to keep natural hazard mortality rates low in comparison to other regions of the world, particularly less privileged ones (e.g. Bründl et al., 2004; Lateltin et al., 2005).

Higher flood mortality rates compared to Switzerland have been reported for Texas (1.08 fatalities per million population per year) as well as several other US states (Sharif et al., 2015) and also for India (1.5; Singh and Kumar, 2013). Coates (1999) found a large decrease in the flood mortality rate in Australia, from 239.8 in the 1800 s to 0.4 in the 1990s. Also, a decreasing frequency of fatalities due to landslides was found in Italy, with 1.8 fatalities per million population per year in 1950 and 1.4 in 1999 (Guzetti, 2000). The average annual rate of fatalities due to lightning found for Switzerland was similar to that reported for the USA $(0.42$; Curran et al., 2000) and considerably lower than that reported for India (approximately 2.5-3.0; Illiyas et al., 2014). However, reports from India differ substantially with other authors recently suggesting much lower mortality rates based on essentially different data sources (0.25; Singh and Singh, 2015). The decrease in lightning-related fatalities found over the last 70 years has also been observed in the USA (López and Holle, 1996) and in England and Wales (Elsom, 2001). In a comparative global summary of published lightning fatality estimates, Singh and Singh (2015) listed a value for 19 th century Switzerland of 6.0 deaths per million population per year, which is more than 10 times the value estimated in our study. Even though this figure was based on only 2 years of data (1876-1877), it illustrates the various improvements (e.g. better medical care, increased awareness) and the socioeconomic changes that have occurred in Switzerland over the past 150 years.

The numbers reported in this section are rough estimates of mortality rates because they are based on the entire population of a political entity. This may lead to a considerable underestimation of the actual mortality rate at a given location. In an alternative approach, to better reflect local or regional mortality rates, we applied a $10 \times 10 \mathrm{~km}$ raster grid which related fatalities to the actual resident population in a given grid cell (Figs. 9 and 10). This method reveals areas in Switzerland, mostly located in high-Alpine environments with mortality rates that are much larger than the average value of 2.5 fatalities per million people and year. A total of 60 cells (out of 485) display values larger than 30 fatalities per million people and year, and 22 cells have rates larger than 150 fatalities per million people and year. This method has considerable shortcomings. The main difficulty is that, depending on the process, other parts of the grid cell are at risk. For example, in grid cells located in the Alps, only a small fraction of the people assigned to this cell really live in or enter a given hazard process zone (e.g. an avalanche zone). Moreover, only approximately half of all fatalities oc- 
curred close to or in the victim's place of residence or the victim's municipality. In many cases the natural hazard victims were killed at a large distance from their home or were from another Swiss region or a foreign country. This confirms that it is very difficult to assess an accurate natural hazard mortality rate. Finally, because gridded population data have only become available recently, it has to be kept in mind that by using current data, the resulting gridded mortality rates (Fig. 10) represent an underestimation (Swiss population has been increasing considerably since the middle of the last century). This also supports our statement that mortality data have to be regarded as a proxy and should be treated with caution.

\subsection{Comparison of natural hazard fatality data with data from other accidental deaths}

In his recent contribution, Goklany (2007) assessed death and death rates due to extreme weather events, such as extreme heat, extreme cold, floods, lightning, tornados and hurricanes. This analysis indicated that globally, as well as for the USA, the aggregate contribution of extreme weather events to overall mortality is relatively small, ranging from $0.03 \%$ (globally) to $0.06 \%$ (USA). More specifically, the global contribution of fatalities due to extreme weather events to all accidental deaths is also quite small $(0.4 \%)$. For example, based on EM-DAT data for 2000-2006 and World Health Organization data for 2002, Goklany (2007) showed that, while roughly 20000 people per year die during extreme weather events, many more are killed in road traffic accidents (approx. 1.2 million people in 2002).

The natural hazard processes considered in the study mentioned above are not exactly the same as in the present study (e.g. heat waves were not considered here and probably not all mass movements were included in Goklany, 2007) and the two study periods differ. Nevertheless, Goklany's point also applies to our Swiss analysis: fatalities and mortality rates from the different hazard processes studied in the present paper are relatively low. A comparison of our data with Swiss road and railroad accident fatality data (Swiss Statistics, www.bfs.admin.ch) confirms the ratio suggested above at the global level. For the same 70-year time frame from 1946 to 2015, a total of 64561 people died on Swiss roads in traffic accidents. This corresponds to an average value of 922 fatalities per year, with a maximum of 1773 deaths in 1971 and a minimum of 243 deaths in 2014. Thus, on average for our study period, more than 60 times as many people were killed in traffic accidents than by natural hazards. Swiss railroad fatalities also clearly outnumbered naturalhazard-related fatalities, although to a lesser extent than traffic fatalities (4871 victims from 1946 to 2014, corresponding to roughly five times the number of natural-hazard-related deaths). Note that both road and railroad fatality numbers show a distinct decrease in Switzerland since the 1970s, sim- ilar to the natural hazard fatality data presented here (Figs. 2 and 3).

Comparing the presented fatality numbers with those of recreational accidents in mountainous terrain, which were not considered in our study (see Sect. 3.4), shows similar patterns. For instance, data from the Swiss Alpine Club (SAC, www.sac-cas.ch) show that mountaineering accidents (e.g. hiking, climbing, canyoning) caused by lightning and rockfall led to 62 fatalities from 2000 to 2013 compared to 21 fatalities in our database for the same two processes (with six fatalities appearing in both data sources). Comparable patterns exist for avalanche fatalities: over the last 20 years (1995/96-2014/15), 15 times more people lost their lives during recreational activities in unsecured terrain than in settlements or on transportation corridors in Switzerland (Techel et al., 2015). On a larger spatial scale covering the whole of the European Alps, this proportion is even more pronounced (a factor of approximately 30 for the 15 years from 2000/01 to 2014/15; Techel et al., 2016). In the vast majority of cases, victims in unsecured terrain triggered the avalanche themselves (e.g. Schweizer and Lütschg, 2001), as opposed to fatalities caused by avalanches in settlements and on transportation routes, in which most avalanches released naturally ( $85 \%$ of the avalanche victims reported in the present study were killed by naturally triggered events).

\section{Conclusions}

In this study, we compiled data from the Swiss flood and landslide damage database and the destructive avalanche database, as well as information collected in an in-depth newspaper search, to establish a new database of fatalities caused by natural hazard processes in Switzerland. For a 70 -year period from 1946 to 2015, we were able to assemble detailed data on 635 events in which 1023 people were killed by processes summarised into seven hazard types (flood, landslide, rockfall, lightning, windstorm, avalanche and other processes). Fatalities that occurred in connection with high-risk sports or certain popular summer and winter outdoor sport activities were not considered. Snow avalanches claimed 378 victims and clearly represent the deadliest natural hazard process in Switzerland. With 164 deaths, less than half as many fatalities were caused by lightning. Floods, windstorms, rockfall events and landslides killed 124, 105, 85 and 74 people, respectively.

Natural hazard fatalities were considerably variable over time. The number of people who died in one single year varied by 1 to 2 orders of magnitude. In 1951 and 1965, fatal events resulted in 112 and 108 deaths, respectively, whereas 5 years had only two fatalities each. For the 70 -year study period, the average and median number of people who died due to natural hazards amounted to 14.6 and 9.0, respectively. Annual loss of life data showed a decrease over time, which was primarily induced by a marked decrease in deaths due to 
avalanches and lightning strikes. The reduction in avalanche fatalities in settlements and on transportation routes is a trend that has also been observed in other European countries and elsewhere. The decrease is due to improvements in both technical (defence structures, preventive artificial release) and organisational (e.g. hazard mapping, emergency planning) measures and to significant progress in avalanche education and forecasting. A reduction in lightning victims over the last century also occurred in many other countries around the world. In Switzerland, the main reasons for this distinct decrease might be that today fewer people work outdoors and there is a much improved awareness of the threat posed by lightning.

Most people were killed by natural hazard events in summer (JJA, $41.7 \%$ of fatalities) and winter (DJF, 32.2\%). Accordingly, the 4 months with the largest number of victims were August (20.2\%), January (14.2\%), February (13.2\%) and July $(12.9 \%)$. While the summer peak mainly occurred due to flood and lightning events (together with one catastrophic ice avalanche in August 1965), the winter peak was caused by snow avalanche incidents. Furthermore, almost two-thirds of the fatalities took place in the afternoon and evening.

Natural hazard fatalities were quite homogeneously distributed over Switzerland. However, mountainous parts of the country (Prealps, Alps) were somewhat more prone to fatal events compared to the Swiss Plateau and the Jura. The reason for this is that avalanche fatalities, and to a slightly lesser extent rockfall and landslide fatalities, occur mainly in the Alpine parts of Switzerland. In contrast, deadly events associated with floods and lightning were observed in practically all regions of Switzerland, with a definite maximum occurring along the Swiss Plateau. Finally, windstorm-related fatalities were mostly observed on the Swiss Plateau, especially on lakes.

The age groups with the largest number of natural hazard victims were the 20-29 and 30-39 year-old groups (172 and 177 , respectively), and almost $50 \%$ of all victims were between 20 and 49 years of age. Young children (0-9 years of age) were the age group that was most underrepresented in the fatality data compared to the Swiss age distribution. Three-quarters of all fatalities were men, and men outnumbered women in all process types except landslides. We assume that this large gender difference was strongly influenced by two factors: firstly, and probably more importantly, virtually all work-related fatality incidents involved physically difficult occupations that put workers at risk and for which the majority of workers are men; second, we speculate that women have a considerably higher risk perception compared to men and that, accordingly, men have a greater disposition towards risk taking than women. Both of these points are (probably) especially relevant for the first half of the study period.

Large catastrophic events with several hundreds of fatalities have occurred in Switzerland in the last 1000 years (e.g.
Basel earthquake of 1356, Goldau rock avalanche of 1806), but not during the period studied here. Apart from the tragic Mattmark ice avalanche of 1965 that killed 88 people, only one landslide and three avalanche events caused more than 10 deaths in the period from 1946 to 2015. Together, these five incidents led to 161 deaths, which correspond to $15.7 \%$ of all fatalities in the data set. Hence, single-fatality events (that account for approximately half of the total natural hazard deaths) and events with only a few victims strongly influence the natural hazard fatality statistics in the recent past. For some process types, such as lightning and rockfall, this influence is particularly strong. When compared with natural hazard mortality rates in other countries or with accidental deaths from other causes in Switzerland, the fatality numbers presented here are quite low. For example, traffic accidents kill an average of approximately 60 times more people than natural hazard events. Nevertheless, we think that current annual natural hazard fatality numbers can still be further reduced by investing in and further developing both structural and organisational (e.g. alarm systems, emergency planning, hazard awareness creation) protection measures. The data set (and analysis) presented here can be used by decision makers at different political levels (municipal, cantonal and federal authorities) to plan and implement such measures.

\section{Data availability}

For data regarding avalanche fatalities please contact the owner of the data, WSL Institute for Snow and Avalanche Research SLF in Davos, Switzerland. Data for other fatalities are available on request from the corresponding author or the Swiss Federal Research Institute WSL in Birmensdorf, Switzerland.

\section{The Supplement related to this article is available online at doi:10.5194/nhess-16-2747-2016-supplement.}

\begin{abstract}
Acknowledgements. We are very grateful to G. Antoniazza, who helped screen many newspaper articles to establish this database. We thank J. Keel, of the Swiss Media Database for excellent support throughout our newspaper search. Furthermore, the authors would like to thank D. Rickenmann, B. McArdell, C. Berger, C. Rickli, E. Maidl, M. Buchecker (all at WSL), U. Mosimann (Swiss Alpine Club), and F. Haslinger (Swiss Seismological Service) for insightful discussions and K. Liechti (WSL) for support with data analysis. We are grateful to staff at the Federal Office for the Environment (FOEN), especially R. Loat and G. R. Bezzola, for their considerable contribution to the maintenance of the Swiss flood and landslide damage database. M. Dawes (WSL) and two anonymous referees are acknowledged for providing constructive comments and improving the quality of the manuscript.
\end{abstract}

Edited by: S. Fuchs

Reviewed by: two anonymous referees 


\section{References}

Ando, M., Ishida, M., Hayashi, Y., Mizuki, C., Nishikawa, Y., and Tu, Y.: Interviewing insights regarding the fatalities inflicted by the 2011 Great East Japan Earthquake, Nat. Hazards Earth Syst. Sci., 13, 2173-2187, doi:10.5194/nhess-13-2173-2013, 2013.

Ashley, S. T. and Ashley, W. S.: Flood fatalities in the United States, J. Appl. Meteorol. Clim., 47, 805-818, doi:10.1175/2007JAMC1611.1, 2008.

Ashley, W. S.: Spatial and temporal analysis of tornado fatalities in the United States: 1880-2005, Weather Forecast., 22, 12141228, doi:10.1175/2007WAF2007004.1, 2007.

Ashley, W. S. and Black, A. W.: Fatalities associated with nonconvective high-wind events in the United States, J. Appl. Meteorol. Clim., 47, 717-725, doi:10.1175/2007JAMC1689.1, 2008.

Auker, M. R., Sparks, R. S. J., Siebert, L., Crosweller, H. S., and Ewert, J.: A statistical analysis of the global historical volcanic fatalities record, Journal of Applied Volcanology, 2, 2, doi:10.1186/2191-5040-2-2, 2013.

Bader, S.: Tornados in der Schweiz, MeteoSchweiz, Zürich, Switzerland, $5 \mathrm{pp}$., available at: http://www.meteoschweiz. admin.ch/content/dam/meteoswiss/de/Klima/Vergangenheit/ Klima-der-Schweiz/doc/klima-tornadobericht-schweiz.pdf (last access: 13 October 2016), 2001 (in German).

Badoux, A., Andres, N., and Turowski, J. M.: Damage costs due to bedload transport processes in Switzerland, Nat. Hazards Earth Syst. Sci., 14, 279-294, doi:10.5194/nhess-14-279-2014, 2014.

BFS: Cantonal portraits 2016, Federal Statistical Office, Neuchâtel, Switzerland, 92 pp., available at: https://www.bfs.admin.ch/bfs/ en/home.html (last access: 8 December 2016), 2016.

Black, A. W. and Ashley, W. S.: Nontornadic convective wind fatalities in the United States, Nat. Hazards, 54, 355-366, doi:10.1007/s11069-009-9472-2, 2010.

Borden, K. A. and Cutter, S. L.: Spatial patterns of natural hazards mortality in the United States, Int. J. Health Geogr., 7, 64, doi:10.1186/1476-072X-7-64, 2008.

Bronaugh, D. and Werner, A.: zyp: Zhang + Yue-Pilon trends package, R package version 0.9-1, http://www.R-project.org (last access: 25 October 2016), 2009.

Bründl, M., Etter, H.-J., Steiniger, M., Klingler, Ch., Rhyner, J., and Ammann, W. J.: IFKIS - a basis for managing avalanche risk in settlements and on roads in Switzerland, Nat. Hazards Earth Syst. Sci., 4, 257-262, doi:10.5194/nhess-4-257-2004, 2004.

Bubeck, P., Botzen, W. J. W., and Aerts, J. C. J. H.: A review of risk perceptions and other factors that influence flood mitigation behavior, Risk Anal., 32, 1481-1495, doi:10.1111/j.15396924.2011.01783.x, 2012.

BWG: Hochwasserschutz an Fliessgewässern, Wegleitung 2001, Bundesamt für Wasser und Geologie, Biel, Switzerland, 72 pp., 2001 (in German).

Chowdhury, A., Mushtaque, R., Bhuyia, A. U., Choudhury, A. Y., and Sen, R.: The Bangladesh cyclone of 1991: Why so many people died, Disasters, 17, 291-304, 1993.

Coates, L.: Flood Fatalities in Australia, 1788-1996, Aust. Geogr., 30, 391-408, doi:10.1080/00049189993657, 1999.

Coates, L., Blong, R., and Siciliano F.: Lightning fatalities in Australia, 1824-1991, Nat. Hazards, 8, 217-233, doi:10.1007/BF00690909, 1993.
Curran, E. B., Holle, R. L., and López, R. E.: Lightning casualties and damages in the United States from 1959 to 1994, J. Climate, 13, 3448-3464, 2000.

Czajkowski, J., Simmons, K., and Sutter, D.: An analysis of coastal and inland fatalities in landfalling US hurricanes, Nat. Hazards, 59, 1513-1531, doi:10.1007/s11069-011-9849-x, 2011

Diakakis, M. and Deligiannakis, G.: Vehicle-related flood fatalities in Greece, Environmental Hazards, 12, 278-290, doi:10.1080/17477891.2013.832651, 2013.

Di Baldassarre, G., Montanari, A., Lins, H., Koutsoyiannis, D., Brandimarte, L., and Blöschl, G.: Flood fatalities in Africa: From diagnosis to mitigation, Geophys. Res. Lett., 37, L22402, doi:10.1029/2010GL045467, 2010.

Dlamini, W. M.: Lightning fatalities in Swaziland: 2000-2007, Nat. Hazards, 50, 179-191, doi:10.1007/s11069-008-9331-6, 2009.

Doocy, S., Rofi, A., Moodie, C., Spring, E., Bradley, S., Burnham, G., and Robinson, C.: Tsunami mortality in Aceh Province, Indonesia, B. World Health Organ., 85, 273-278, 2007.

Dowling, C. A. and Santi, P. M.: Debris flows and their toll on human life: a global analysis of debris-flow fatalities from 1950 to 2011, Nat. Hazards, 71, 203-227, doi:10.1007/s11069-0130907-4, 2014.

Elsom, D. M.: Deaths and injuries caused by lightning in the United Kingdom: analyses of two databases, Atmos. Res., 56, 325-334, doi:10.1016/S0169-8095(00)00083-1, 2001.

EM-DAT: available at: http://www.emdat.be, last access: 27 June 2016.

Etter, H. J., Stucki, T., Zweifel, B., and Pielmeier, C.: Developments in avalanche forecasting and other prevention measures and their potential effect on avalanche fatalities, in: Proceedings International Snow Science Workshop ISSW, Whistler, Canada, 21-27 September 2008, 628-635, 2008.

Fäh, D., Gisler, M., Jaggi, B., Kästli, P., Lutz, T., Masciadri, V., Matt, C., Mayer-Rosa, D., Rippmann, D., Schwarz-Zanetti, G., Tauber, J., and Wenk, T.: The 1356 Basel earthquake: an interdisciplinary revision, Geophys. J. Int., 178, 351-374, doi:10.1111/j.1365-246X.2009.04130.x, 2009.

FitzGerald, G., Du, W., Jamal, A., Clark, M., and Hou, X.Y.: Flood fatalities in contemporary Australia (1997-2008), Emerg. Med. Australas., 22, 180-186, doi:10.1111/j.17426723.2010.01284.x, 2010.

Fuchs, S. and Zischg, A.: Vulnerabilitätslandkarte Österreich, IAN Report 152, Institut für Alpine Naturgefahren, Universität für Bodenkultur, Wien, 2014 (in German).

Gerritsen, H.: What happened in 1953? The Big Flood in the Netherlands in retrospect, Philos. T. Roy. Soc. A, 363, 12711291, doi:10.1098/rsta.2005.1568, 2005.

Giardini, D., Wiemer, S., Fäh, D., and Deichmann, N.: Seismic Hazard Assessment of Switzerland, 2004, Swiss Seismological Service, ETH Zurich, Zurich, available at: http:// www.seismoatschool.ethz.ch/Hazard_report_2004.pdf (last access: 27 June 2016), 2004.

Goklany, I. M.: Death and death rates due to extreme weather events (Global and U.S. trends, 1900-2006), in: The Civil Society Report on Climate Change, International Policy Press, London, UK, available at: http://goklany.org/ library/deathsdeathratesfromextremeevents2007.pdf (last access: 27 June 2016), 2007. 
Guzzetti, F.: Landslide fatalities and the evaluation of landslide risk in Italy, Eng. Geol., 58, 89-107, doi:10.1016/S00137952(00)00047-8, 2000.

Hilker, N., Badoux, A., and Hegg, C.: The Swiss flood and landslide damage database 1972-2007, Nat. Hazards Earth Syst. Sci., 9, 913-925, doi:10.5194/nhess-9-913-2009, 2009.

Holle, R. L.: A summary of recent national-scale lightning fatality studies, Weather, Climate, and Society, 8, 35-42, doi:10.1175/WCAS-D-15-0032.1, 2016.

Höller, P.: Avalanche cycles in Austria: an analysis of the major events in the last 50 years, Nat. Hazards, 48, 399-424, doi:10.1007/s11069-008-9271-1, 2009.

Illiyas, F. T., Mohan, K., Mani, S. K., and Pradeepkumar, A. P.: Lightning risk in India: Challenges in disaster compensation, Econ. Polit. Weekly, XLIX, 23-27, 2014.

Inoue, S., Wijeyewickrema, A. C., Matsumoto, H., Miura, H., Gunaratna, P., Madurapperuma, M., and Sekiguchi, T.: Field Survey of Tsunami Effects in Sri Lanka due to the Sumatra-Andaman Earthquake of December 26, 2004, Pure Appl. Geophys., 164, 395-411, doi:10.1007/s00024-006-0161-8, 2007.

Ins. Inf. Inst.: available at: http://www.iii.org/fact-statistic/ catastrophes-global, last access: 27 June 2016.

Jamieson, J. B., Haegeli, P., and Gauthier, D. M.: Avalanche Accidents in Canada, Volume 5 (1996-2007), Canadian Avalanche Association, Revelstoke, Canada, ISBN-13: 978-0-9866597-4-4, 429 pp., 2010.

Jarry, F.: 40 ans d'accidents d'avalanche ... 40 ans de prévention, Neige et Avalanches, 135, 18-22, 2011 (in French).

Jensenius, J. S.: A detailed analysis of recent lightning deaths in the United States, in: Fifth International Lightning Meteorology Conference, Tucson, USA, 20-21 March 2014, 1-8, available at: http://www.vaisala.com/en/events/ildcilmc/Pages/ ILDC-2014-archive.aspx (last access: 10 October 2016), 2014.

Jonkman, S. N.: Global perspectives on loss of human life caused by floods, Nat. Hazards, 34, 151-175, doi:10.1007/s11069-0048891-3, 2005.

Jonkman, S. N., Maaskant, B., Boyd, E., and Levitan, M. L.: Loss of life caused by the flooding of New Orleans after hurricane Katrina: analysis of the relationship between flood characteristics and mortality, Risk Anal., 29, 676-698, doi:10.1111/j.15396924.2008.01190.x, 2009.

Kristensen, K.: A Survey of Avalanche Accidents in Norway, in: 25 years of Snow Avalanche Research, edited by: Hestnes, E., NGI Publication, 203, Oslo, Norway, 155-159, 1998.

Kure, S., Jibiki, Y., Quimpo, M., Manalo, U. N., Ono, Y., and Mano, A.: Evaluation of the Characteristics of Human Loss and Building Damage and Reasons for the Magnification of Damage Due to Typhoon Haiyan, Coast. Eng. J., 58, 1640008, doi:10.1142/S0578563416400088, 2016.

Lateltin, O., Haemmig, C., Raetzo, H., and Bonnard, C.: Landslide risk management in Switzerland, Landslides, 2, 313-320, doi:10.1007/s10346-005-0018-8, 2005.

Lindell, M. K. and Hwang, S. N.: Households' perceived personal risk and responses in a multihazard environment, Risk Anal., 28, 539-556, doi:10.1111/j.1539-6924.2008.01032.x, 2008.

López, R. E. and Holle, R. L.: Fluctuations of lightning casualties in the United States: 1959-1990, J. Climate, 9, 608-615, 1996.
López, R. E., Holle, R. L., and Heitkamp, T. A.: Lightning casualties and property damage in Colorado from 1950 to 1991 based on Storm Data, Weather Forecast., 10, 114-126, 1995.

Margreth, S., Stoffel, L., and Wilhelm, C.: Winter opening of high alpine pass roads - Analysis and case studies from the Swiss Alps, Cold Reg. Sci. Technol., 37, 467-482, doi:10.1016/S0165232X(03)00085-5, 2003.

McLeod, A. I.: Kendall: Kendall rank correlation and MannKendall trend test, R package version 2.2, avaialable at: https: //cran.r-project.org/web/packages/Kendall/Kendall.pdf (last access: 25 October 2016), 2015.

MunichRe: Topics Geo (Natural catastrophes 2015 - Analyses assessments, positions), Munich RE, Munich, Germany, 2016.

Navarrete-Aldana, N., Cooper, M. A., and Holle, R. L.: Lightning fatalities in Colombia from 2000 to 2009, Nat. Hazards, 74, 1349-1362, doi:10.1007/s11069-014-1254-9, 2014.

Noji, E. K.: Natural disasters, Crit. Care Clin., 7, 271-292, 1991.

Page, C. E., Atkins, D., Shockley, L. W., and Yaron, M.: Avalanche deaths in the United States: a 45-year analysis, Wild. Environ. Med., 10, 146-151, 1999.

Paulikas, M. J. and Rahman, M. K.: A temporal assessment of flooding fatalities in Pakistan (1950-2012), Journal of Flood Risk Management, 8, 62-70, doi:10.1111/jfr3.12084, 2015.

Petley, D.: Global patterns of loss of life from landslides, Geology, 40, 927-930, doi:10.1130/G33217.1, 2012.

Petrascheck, A.: Die Hochwasser 1868 und 1987 - Ein Vergleich, Wasser Energie Luft, 81, 1-8, 1989 (in German).

Rappaport, E. N.: Loss of life in the United States associated with recent Atlantic tropical cyclones, B. Am. Meteorol. Soc., 81, 2065-2073, 2000.

Röthlisberger, G.: Chronik der Unwetterschäden in der Schweiz, Eidg. Forschungsanstalt WSL, Birmensdorf, Switzerland, Berichte der Eidgenössischen Forschungsanstalt WSL, 330, 122 pp., 1991 (in German).

SAC: available at: http://www.sac-cas.ch, last access: 27 June 2016.

Schmid, F., Fraefel, M., and Hegg C.: Unwetterschäden in der Schweiz 1972-2002: Verteilung, Ursachen, Entwicklung, Wasser Energie Luft, 96, 21-28, 2004 (in German).

Schneebeli, M., Laternser, M., Föhn, P., and Ammann, W.: Wechselwirkungen zwischen Klima, Lawinen und technischen Massnahmen, Schlussbericht NFP31, vdf-Hochschulverlag, Zürich, 134 pp., 1998 (in German).

Schweizer, J. and Lütschg, M.: Characteristics of humantriggered avalanches, Cold Reg. Sci. Technol., 33, 147-162, doi:10.1016/S0165-232X(01)00037-4, 2001.

Sepúlveda, S. A. and Petley, D. N.: Regional trends and controlling factors of fatal landslides in Latin America and the Caribbean, Nat. Hazards Earth Syst. Sci., 15, 1821-1833, doi:10.5194/nhess-15-1821-2015, 2015.

Shah, B. V.: Is the environment becoming more hazardous? - A global survey 1947 to 1980, Disasters, 7, 202-209, doi:10.1111/j.1467-7717.1983.tb00822.x, 1983.

Sharif, H. O., Jackson, T. L., Hossain, M. M., and Zane, D.: Analysis of Flood Fatalities in Texas, Nat. Hazards Review, 16, 04014016, doi:10.1061/(ASCE)NH.1527-6996.0000145, 2015.

Singh, O. and Kumar, M.: Flood events, fatalities and damages in India from 1978 to 2006, Nat. Hazards, 69, 1815-1834, doi:10.1007/s11069-013-0781-0, 2013. 
Singh, O. and Singh, J.: Lightning fatalities over India: 1979-2011, Meteorol. Appl., 22, 770-778, doi:10.1002/met.1520, 2015.

SLF: Der Lawinenwinter 1999, Ereignisanalyse, Eidg. Institut für Schnee- und Lawinenforschung, Davos, Switzerland, 588 pp., 2000 (in German).

Stoffel, L.: Künstliche Lawinenauslösung, Praxishilfe (2. überarbeitete Auflage), Eidg. Institut für Schnee- und Lawinenforschung, Davos, Switzerland, Mitt. Eidgenöss. Inst. SchneeLawinenforsch., 53, 66 pp., 2001 (in German).

Swiss Statistics: available at: http://www.bfs.admin.ch/bfs/portal/ en/index.html, last access: 27 June 2016.

Techel, F. and Zweifel, B.: Recreational avalanche accidents in Switzerland: trends and patterns with an emphasis on burial, rescue methods and avalanche danger, in: Proceedings International Snow Science Workshop ISSW, Grenoble, France, 7-11 October 2013, 1106-1112, 2013.

Techel, F., Zweifel, B., and Marty, C.: Schnee und Lawinen in den Schweizer Alpen, Hydrologisches Jahr 2014/15, Eidg. Forschungsanstalt WSL, Birmensdorf, Switzerland, WSL Bericht, 37, 83 pp., 2015 (in German).

Techel, F., Jarry, F., Kronthaler, G., Mitterer, S., Nairz, P., Pavšek, M., Valt, M., and Darms, G.: Avalanche fatalities in the European Alps: long-term trends and statistics, Geogr. Helv., 71, 147-159, doi:10.5194/gh-71-147-2016, 2016.
Tekeli-Yeşil, S., Dedeoğlu, N., Braun-Fahrlaender, C., and Tanner, M.: Earthquake awareness and perception of risk among the residents of Istanbul, Nat. Hazards, 59, 427-446, doi:10.1007/s11069-011-9764-1, 2011.

Tsai, Y.-B., Yu, T.-M., Chao, H.-L., and Lee, C.-P.: Spatial distribution and age dependence of human-fatality rates from the ChiChi, Taiwan, earthquake of 21 September 1999, B. Seismol. Soc. Am., 91, 1298-1309, doi:10.1785/0120000740, 2001.

Vranes, K. and Pielke Jr., R.: Normalized earthquake damage and fatalities in the United States: 1900-2005, Nat. Hazards Review, 10, 84-101, doi:10.1061/(ASCE)1527-6988(2009)10:3(84), 2009.

Wilhelm, C.: Wirtschaftlichkeit im Lawinenschutz: Methodik und Erhebungen zur Beurteilung von Schutzmassnahmen mittels quantitativer Risikoanalyse und ökonomischer Bewertung, $\mathrm{PhD}$ thesis, ETH Zurich, Switzerland, 309 pp., available at: doi:10.3929/ethz-a-001766318, 1997 (in German).

WSL and BUWAL: Lothar, Der Orkan 1999, Ereignisanalyse, Birmensdorf \& Bern, Switzerland, Eidgenössischen Forschungsanstalt WSL, Bundesamt für Umwelt, Wald und Landschaft BUWAL, 365 pp., 2001 (in German). 